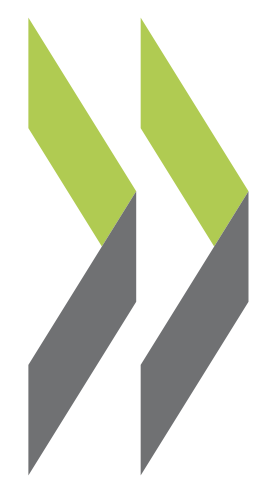

OECD Economics Department Working Papers No. 1448

\section{Export and productivity in global value chains:}

Comparative evidence from

Latvia and Estonia
Konstantins Benkovskis,

Jaan Masso,

Olegs Tkacevs,

Pritit Vahter,

\section{Naomitsu Yashiro}


Organisation de Coopération et de Développement Économiques

Organisation for Economic Co-operation and Development

11-Dec-2017

ECONOMICS DEPARTMENT

English - Or. English

\section{EXPORT AND PRODUCTIVITY IN GLOBAL VALUE CHAINS : COMPARATIVE EVIDENCE} FROM LATVIA AND ESTONIA

ECONOMICS DEPARTMENT WORKING PAPERS No. 1448

By Konstantins Benkovskis, Jaan Masso, Olegs Tkacevs, Priit Vahter and Naomitsu Yashiro

OECD Working Papers should not be reported as representing the official views of the OECD or of its member countries. The opinion expressed and arguments employed are those of the author(s).

Authorised for publication by Alvaro Pereira, Director, Country Studies Branch, Economics Department.

All Economics Department Working Papers are available at www.oecd.org/eco/workingpapers.

JT03424555

This document, as well as any data and map included herein, are without prejudice to the status of or sovereignty over any territory, to the delimitation of international frontiers and boundaries and to the name of any territory, city or area. 
OECD Working Papers should not be reported as representing the official views of the OECD or of its member countries. The opinions expressed and arguments employed are those of the author(s).

Working Papers describe preliminary results or research in progress by the author(s) and are published to stimulate discussion on a broad range of issues on which the OECD works.

Comments on Working Papers are welcomed, and may be sent to OECD Economics Department, 2 rue André-Pascal, 75775 Paris Cedex 16, France, or by e-mail to eco.contact@oecd.org.

All Economics Department Working Papers are available at www.oecd.org/eco/workingpapers.

This document and any map included herein are without prejudice to the status of or sovereignty over any territory, to the delimitation of international frontiers and boundaries and to the name of any territory, city or area.

The statistical data for Israel are supplied by and under the responsibility of the relevant Israeli authorities. The use of such data by the OECD is without prejudice to the status of the Golan Heights, East Jerusalem and Israeli settlements in the West Bank under the terms of international law.

\section{C) OECD (2017)}

You can copy, download or print OECD content for your own use, and you can include excerpts from OECD publications, databases and multimedia products in your own documents, presentations, blogs, websites and teaching materials, provided that suitable acknowledgment of OECD as source and copyright owner is given. All requests for commercial use and translation rights should be submitted to rights@oecd.org 
ECO/WKP(2017)80

\section{ABSTRACT/RÉSUMÉ \\ Export and productivity in global value chains - Comparative Evidence from Latvia and Estonia}

This paper investigates the effect of export entry on productivity, employment and wages of Latvian and Estonian firms in the context of global value chain (GVC). Like in many countries, exporting firms in Latvia and Estonia are more productive, larger, pay higher wages and are more capital intensive than nonexporting firms. While this is partly because firms that are originally more productive and have better performances are more likely to enter export, Latvian and Estonian firms also realise more than $23 \%$ and $14 \%$ higher labour productivity level as the result of export entry. Export entry also increases employment and average wages. Gains in productivity and employment are particularly large when firms enter exports that are related to participation in knowledge-intensive activities found in the upstream of GVC. For instance, Latvian firms that start exporting intermediate goods or non-transport services (which include knowledge intensive services) enjoy significantly higher productivity gains than those starting to export final goods or transport services. These findings underscore the importance of innovation policies that strengthen firms' capabilities to supply highly differentiated knowledge-intensive goods and services to GVC.

This Working Paper relates to the 2017 OECD Economic Survey of Latvia (http://www.oecd.org/eco/surveys/economic-survey-latvia.htm).

Key words: productivity, global value chain, export, Latvia, Estonia

JEL: F12, F14, O19, O57

$* * * * * * * * * * * * *$

Exportation et productivité dans les chaînes de valeur mondiales : données comparatives sur la Lettonie et l'Estonié

Cet article étudie l'effet de l'activité d'exportation sur la productivité, l'emploi et les salaires dans les entreprises lettones et estoniennes qui participent aux chaînes de valeur mondiales (CVM). Comme dans beaucoup d'autres pays, les entreprises exportatrices de Lettonie et d'Estonie sont plus productives, plus grandes, plus généreuses avec leurs salariés et plus capitalistiques que les entreprises qui n'exportent pas. Si cela tient en partie au fait que les entreprises initialement plus productives et plus performantes sont aussi plus enclines à exporter, les entreprises lettones et estoniennes réalisent respectivement un gain de productivité du travail de plus de $23 \%$ et $14 \%$ grâce à leurs activités d'exportation. Celles-ci se traduisent aussi par une augmentation de l'emploi et des salaires moyens. Les gains de productivité et d'emploi sont d'autant plus importants que les entreprises exportatrices prennent pied à l'étranger dans des secteurs à forte intensité de savoir situés en amont de la CVM. Par exemple, les entreprises lettones qui commencent à exporter des biens intermédiaires ou des services non liés au transport (parmi lesquels des services de haute intensité de savoir) affichent des gains de productivité plus élevés que celles qui commencent à exporter des produits finis ou des services de transport. Ces constatations amènent à souligner l'importance des politiques d'innovation pour renforcer la capacité des entreprises à fournir aux CVM des biens et des services très différenciés et à forte valeur ajoutée.

Ce Document de travail se rapporte à l'Étude économique de l'OCDE de la Lettonie 2017 (http://www.oecd.org/fr/eco/etudes/etude-economique-lettonie.htm).

Mots-clés: productivité, chaîne de valeur mondiale, exportation, Lettonie, Estonie

JEL: F12, F14, O19, O57 


\section{TABLE OF CONTENTS}

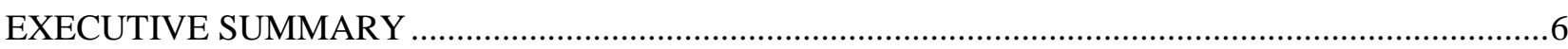

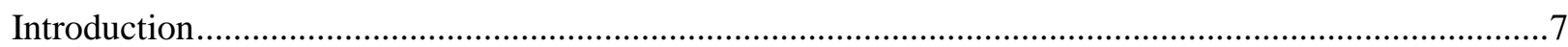

Data

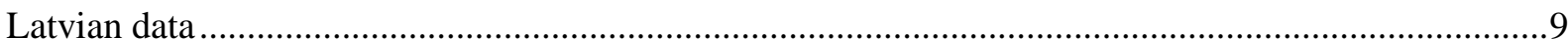

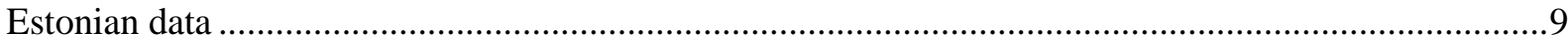

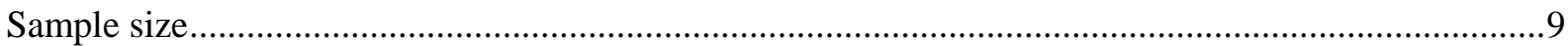

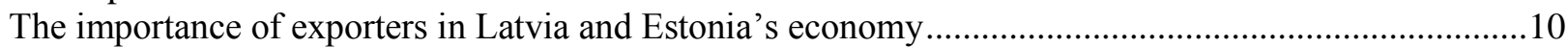

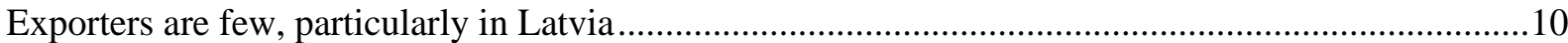

Exporters account for a large share of total employment and turnover.................................................11

Exports are concentrated among a few large exporters ......................................................................12

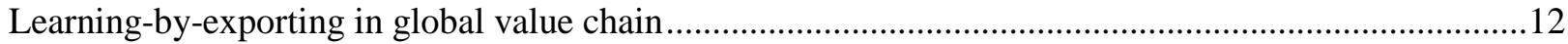

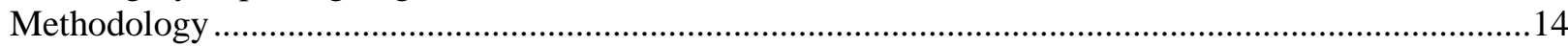

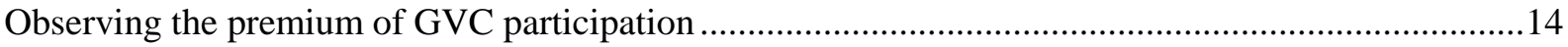

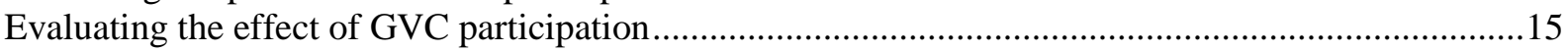

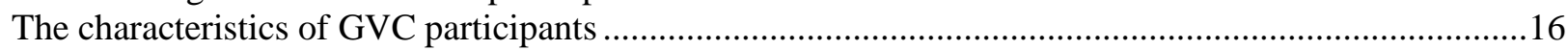

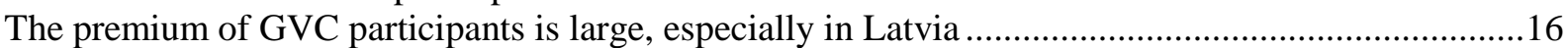

GVC participants have higher productivity distribution than non-exporters .....................................18

There are many firms that are too unproductive to enter export markets..............................................19

Many productive firms are held back from entering export markets ..................................................20

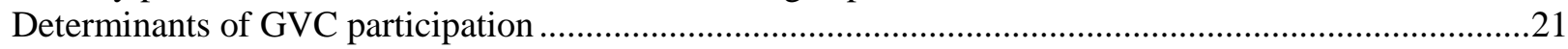

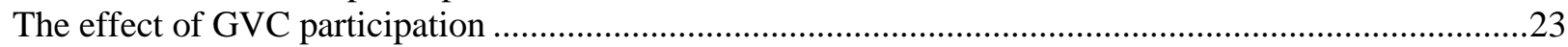

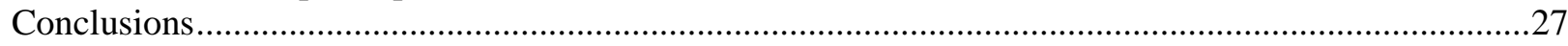

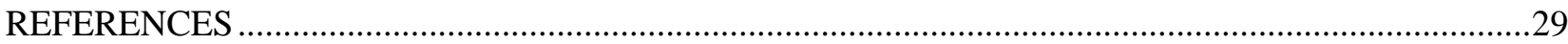

APPENDIX 1. THE ROLE OF SKILLS IN EXPORT ENTRY OF ESTONIAN FIRMS...........................32

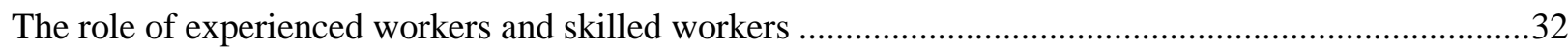

Knowledge spillovers from multinational enterprises through workers' mobility ...................................34

APPENDIX 2. EXPORTS AND INNOVATION OF ESTONIAN FIRMS ................................................36

\section{Tables}

1. The sample size of the baseline data of Latvian and Estonian firms .................................................10

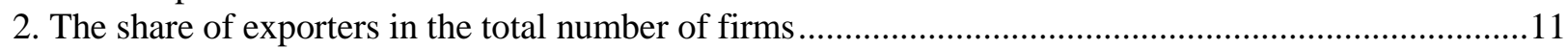

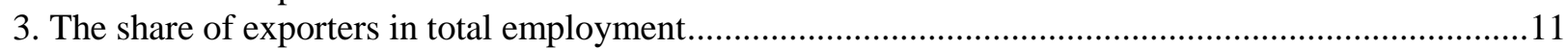

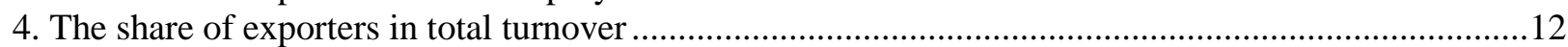

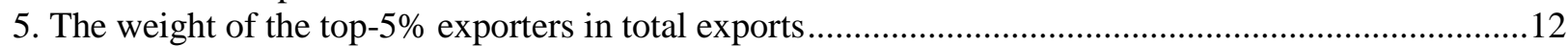

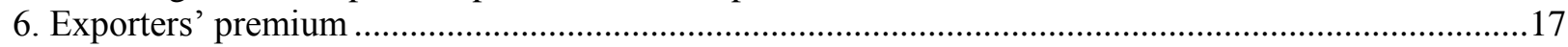

7. The gap and overlap in the productivity distributions of exporters and non-exporters, $\%$...................20

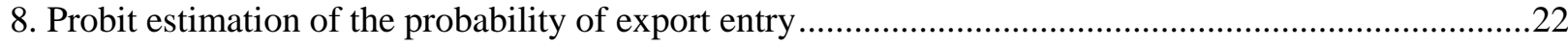

9. Mean values of main determinants of export entry before and after matching...................................24

10. The effect of export entry on productivity and other measures of performance ................................26

11. The employment share of workers with export experience and skill composition ...............................33

12. Regression coefficients of export experience and skills intensity ......................................................34

13. MNE experience of employees: estimated relationship with exporting …........................................35 


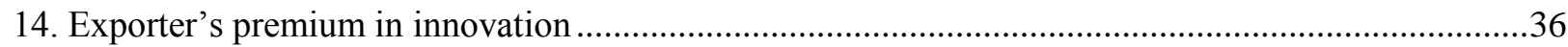

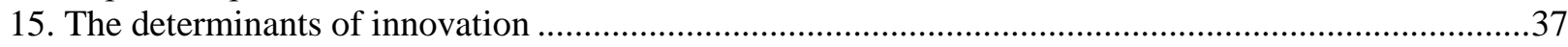

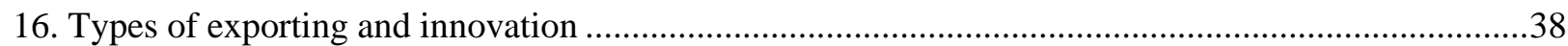

\section{Figures}

Figure 1. Labour productivity distribution of exporters versus non-exporters ...................................18

Figure 2. Labour productivity distribution of goods exporters versus non-exporters...........................19

Figure 3. Labour productivity distribution of service exporters versus non-exporters .........................19 


\title{
EXPORT AND PRODUCTIVITY IN GLOBAL VALUE CHAINS: COMPARATIVE EVIDENCE FROM LATVIA AND ESTONIA
}

\author{
By Konstantins Benkovskis, Jaan Masso, Olegs Tkacevs, Priit Vahter and Naomitsu Yashiro ${ }^{1}$
}

\section{EXECUTIVE SUMMARY}

This joint research by the OECD, the Bank of Latvia and the University of Tartu, Estonia, explores the effect of export entry on productivity, employment and wages of Latvian and Estonian firms in the context of global value chains (GVCs). It provides comparative analysis on the characteristics of exporters in the two countries and estimates the effect of export entry on productivity, employment and wages using propensity score matching. The research then explores whether these effects differs between exports associated with participation in different segments of GVCs, in particular, in the upstream or in the downstream of GVCs. It is found that:

- Like in many countries, only a few Latvian and Estonian firms export. In 2014, $6 \%$ of Latvian firms and 12\% of Estonian firms exported. The lower export participation of Latvian as compared to Estonian firms is a puzzle. One possible explanation is that Latvia's micro enterprise tax, which was introduced in 2011, encourages firms to remain small or split into smaller firms that are unable to cover the large entry costs of export. However, considering that there are more micro enterprises in Estonia, this cannot be the main reason.

- Exporting firms are more productive, larger, pay higher wages and use more capital per worker than non-exporting firms. In Latvia and Estonia respectively, they exhibit on average $80 \%$ and $61 \%$ higher labour productivity, employ more than twice as many and 33\% more workers, pay $62 \%$ and $48 \%$ higher wages and use $77 \%$ and $40 \%$ more capital per worker than non-exporting firms.

- Higher labour productivity and larger firm size increase the chance that a firm starts exporting. There are also other factors that facilitate export entry, such as hiring of workers and managers experienced with foreign markets.

- After controlling for the self-selection of more productive and larger firms into export, it is found that export entry boosts the level of labour productivity by more than $23 \%$ (14\%) among Latvian (Estonian) firms, increases employment by up to $21 \%$ (10\%) among Latvian (Estonian) firms and also increases average wages of Latvian (Estonian) firms by up to $8 \%(7 \%)$.

- Export entry related to participation in well remunerated activities often found in the upstream of GVCs results in significant productivity and employment gains of Latvian firms. This is the case for starting exporting intermediate goods, re-exports and non-transport services. By contrast, exporting final goods or transport services yields little or no productivity or employment gains.

\footnotetext{
Konstantins Benkovskis is an adviser at the Bank of Latvia and associate professor at Stockholm School of Economics in Riga, Latvia. Jaan Masso and Priit Vahter are senior research fellows at the School of Economics and Business Administration of the University of Tartu, Estonia. Olegs Tkacevs is an economist at the Bank of Latvia. Naomitsu Yashiro is an economist at the Economics Department in the OECD. This joint research has been conducted as an input to the 2017 OECD Economic Survey of Latvia. The authors are grateful for valuable comments by Jaanika Meriküll (Esti Pank), Sonia Araujo, Elena Rustichelli, Asa Johansson, Daniela Glocker, Andrés Fuentes Hutfilter, Robert Ford (OECD/Economics Department), Sebastian Benz (OECD/Trade and Agriculture Directorate) and participants at the OECD Economics Department Brown Bag Seminar. Special thanks are due to Dacil Kurzweg and Sisse Nielsen (OECD/Economics Department) for editorial supports.
} 
While productivity gains from export entry are found across all types of exports in Estonia, they are the largest for exports of non-transport services.

Policies that enhance resource allocation and innovation can promote productivity growth by broadening the scope of firms participating in GVCs, especially in the upstream of GVCs.

\section{Introduction}

International trade is increasingly shaped by global value chain $(\mathrm{GVC})^{2}$. Participation in GVC is considered to offer countries opportunities for knowledge transfers from multinational enterprises and intensive use of technologically advanced imported inputs that would boost productivity (OECD, 2013). Yet, aside from case studies, the empirical evidence of the effect of GVC participation on firm-level productivity is scant. This paper exploits microdata of Latvian and Estonian firms to assess whether participation in GVCs through export raises productivity, employment and wages. In particular, the paper explores whether such effects differ across different activities found in the upstream or downstream of GVC. $^{3}$

Prior empirical literature that investigated the causal relationship between productivity and export has found abundant evidence on the self-selection of more productive firms into export (Bernard and Jensen, 1999; 2004). On the other hand, evidence of productivity improvements following export entry - the socalled 'learning-by-exporting' effects - are far from established. A large share of empirical studies shows that there is no evidence of statistically significant learning-by-exporting effects, suggesting that the large exporter productivity premium reflects primarily the self-selection ${ }^{4}$. Some authors, however, have found evidence supporting the learning-by-exporting hypothesis ${ }^{5}$. There is some evidence in favour of larger learning effects in the case of exporting to more advanced economies (de Loecker 2007) or following entry with certain export strategies (Masso and Vahter, 2015). However, to our knowledge, there have been no attempts to assess learning-by-exporting in the context of GVC.

Latvia and Estonia are suitable countries for studying the effect of GVC participation on productivity. Due to the small size of their economies, access to the foreign markets is essential for their firms to take advantage of economies of scale and to make major qualitative changes such as upgrading technologies or improving skills. At the same time, the low level of productivity in Estonia and Latvia, compared to the high income OECD countries, is one of key development challenges for the two countries. Higher productivity is also key for those countries to converge to the income level of the rich OECD countries (OECD, 2017a, 2017b). Strong upward pressure on wages (due to labour shortages related to international outward migration and population ageing) makes achieving higher productivity even more essential.

\footnotetext{
${ }^{2}$ See for instance: Hummels et al. (2001), Yi (2003) for earlier work on the role of GVC in the rapid growth in trade volume; Koopman et al., $(2012,2014)$ for the implication of GVC in the value added contents of trade flow; OECD (2013) for various policy implications of GVCs.

${ }^{3}$ Admittedly, participation in GVC can take place through other channel than exports, such as supplying the local affiliates of MNEs. This research focus on GVC participation through exports which is - still the most predominant form of a firm's internationalisation and also due to the relatively low FDI penetration in Latvia and Estonia compared to other emerging European countries such as Czech Republic or Slovakia (OECD, 2017).

${ }^{4}$ See Wagner (2012), Greenaway and Kneller (2007) for an overview and Bernard and Jensen $(1999,2004)$ for examples of early and influential empirical investigations.

${ }^{5}$ For example, de Loecker (2007, 2013), Blalock and Gertler (2004), van Biesebroeck (2005), Aw et al. (2007) and Masso and Vahter (2015).
} 
This paper identifies the effect of entry into several types of export that are related to participation in different segments of GVC. The types of exports considered are exports of intermediate and final goods, re-exporting as well as exports of transport and non-transport services. For example, exports of intermediate goods and non-transport services (which include knowledge intensive services such as R\&D and ICT services) are interpreted as participation in knowledge-intensive activities often found in the upstream of GVC. The analysis is based on the most recent administrative firm-level data available for Latvia and Estonia. The inclusion of service exporters relates this study to a relatively small range of studies that uses service trade firm-level data (such as Criscuolo and Breinlich, 2011).

The paper finds that export entry results in a higher productivity level for Latvian and Estonian firms. The gains in productivity are long lasting. However, the magnitude of productivity gains differs across types of exports. Entry into exporting of intermediate goods or non-transport services results in sizable and statistically significant gains in productivity. On the other hand, productivity gains from entry into exporting of final goods or transport service are small or insignificant. These findings are in line with observations that knowledge and technology intensive activities in the upstream of GVC generates greater value added than often labour intensive activities (such as assembly) found in the downstream of GVC (Gereffi, 1999; Dedrick et al., 2010; Baldwin, 2012).

Another novel contribution of this paper is the comparative analysis of learning-by-exporting between two Baltic countries that share similar country sizes, geographic conditions and industrial structure. Despite similar fundamental environments, the two countries differ in terms of institutional framework that may affect the internationalisation of firms. In 2010, Estonia completed the accession process to the OECD, which required implementing a wide range of structural reforms to improve public governance and enhance competition. Latvia joined the OECD more recently in 2016, undergoing the same process. While sizable informal economic activities constitute a problem in both countries, some aspects such as underreporting of corporate profits are considered to be more widespread in Latvia (Putniņš and Sauka, 2016). Furthermore, in 2000, Estonia introduced a corporate income tax reform which only taxes distributed profits, reducing the incentives to hide corporate profits (Masso, Meriküll, Vahter, 2013). Latvia introduced a similar tax reform in 2017. While the paper does not attempt to identify the effects of specific tax regimes or regulations on export entry or the size of productivity gains following export entry, the comparative analysis provides insights on the possible role of institutions in facilitating participation in GVCs.

The rest of the paper is structured as follows. The next section describes the datasets used in the study as well as the methodology employed. The third section provides an analysis of exporting firms, including various performance measures across different types of engagement in international trade. The fourth section explores the determinants of export entry by estimating the probability of export entry as a function of firms' characteristics. Besides well-known determinants such as ex-ante productivity level, the section also explores the role of human capital namely the hiring of skilled workers and managers with experience in the foreign markets. The fifth section estimates the impact of entry into different types of exports on firm productivity by applying the propensity score matching (PSM), widely used in micro studies including those that examine learning-by-exporting effects. The final section concludes with some policy implications.

\section{Data}

This paper exploits administrative firm-level datasets comprising data on financial statements and international trade of Latvian firms over the period 2006 to 2014 and Estonian firms over 1995 to 2014. For some additional analysis, these data are merged with other firm-level data and employer-employee 
data $^{6}$. Data processing was harmonised to the largest possible extent between the Latvian and Estonian datasets to allow comparison between these two countries.

\section{Latvian data}

Data on financial statements was obtained from Firms' indicators comprehensive database of the Central Statistical Bureau (CSB) of Latvia, which is based on information from the State Revenue Service. It contains Latvian firms' balance sheet data, data from profit and loss statements including turnover, the number of persons employed, compensation of employees and value added. It also includes information on the sector of activity according to the two-digit NACE 2 classification. The number of firms included in the dataset varies from 61,159 in 2006 to 99,466 in 2014. The dataset is complemented by Firms' foreign assets and liabilities dataset of the Bank of Latvia, which allows identifying the foreign capital share of companies as well as the countries of origin of capital owners.

The dataset is matched with the Goods trade database of the CSB which includes information on merchandise flows (exports and imports), where merchandises are classified according to the eight-digit Combined Nomenclature (CN8) classification, the partner country, statistical value of transaction (in f.o.b. prices for exports and c.i.f. prices for imports), net weight of traded goods in kilograms, as well as product volume in supplementary measures (if available), and time period of the trade flow (year and month). It is matched with the Services trade database of the Bank of Latvia, which provides information on all types of services apart from travel, construction, insurance and government services for which detailed firm-level information is not collected. Unlike the Goods trade database, the service trade database does not include information on the partner country. The matched data are available for the period 2006-2014 ${ }^{7}$

\section{Estonian data}

Data on financial statements come from the Estonian Business Registry by Statistics Estonia, which includes information on balance sheets, profit and loss statements, cash flow statements and general information such as 5-digit industry classification codes, ownership, number of employees, turnover by industries. It is complemented by Statistical Profile of Enterprises by Statistics Estonia which provides information about foreign ownership, numbers of employees, turnover, legal form etc. This is matched with the International goods trade dataset by Statistics Estonia based on the customs statistics. The Business Registry dataset is also matched with the Services trade dataset by the Bank of Estonia which includes exports and imports of various types of services. The dataset includes information on the destination country. All datasets are available for the period 1995 - 2014 except the services trade dataset which is only available for the period 2005-2014.

\section{Sample size}

This paper excludes firms in the following sectors: agriculture and mining (NACE 01-09), energy and water supply (NACE 35-39), construction (NACE 41-43), and public services (NACE 84-99). In addition, samples with extremely labour productivity or capital productivity exceeding the $99^{\text {th }}$ percentile or lower than the $1^{\text {st }}$ percentile of the distribution were dropped. After such data cleaning, about 40000 to 70000 Latvian firms are included in the analysis each year. For Estonia, the sample size reaches 100000 in the most recent year. Firms with less than 10 employees account for more than $80 \%$ of the sample in both countries. The share of those very small firms has increased over time, particularly in Estonia (Table 1).

\footnotetext{
${ }^{6}$ For additional analysis, where those datasets are matched with individual-level data to create employer-employee dataset, the time span is shorter due to the limited availability of the individual data.

${ }^{7}$ The matched data are anonymous (i.e. individual firms cannot be identified).
} 
Table 1. The sample size of the baseline data of Latvian and Estonian firms

\begin{tabular}{|c|c|c|c|c|}
\hline & \multicolumn{2}{|c|}{ Latvia } & \multicolumn{2}{|c|}{ Estonia } \\
\hline & All firms & $\begin{array}{l}\text { The share of } \\
\text { firms with } \\
\text { less than } 10 \\
\text { employees } \\
(\%)\end{array}$ & All firms & $\begin{array}{c}\text { The share of } \\
\text { firms with } \\
\text { less than } 10 \\
\text { employees } \\
(\%)\end{array}$ \\
\hline 1995 & & & 15799 & 79.0 \\
\hline 1996 & & & 17127 & 77.7 \\
\hline 1997 & & & 21984 & 78.2 \\
\hline 1998 & & & 26256 & 79.4 \\
\hline 1999 & & & 29121 & 80.8 \\
\hline 2000 & & & 32235 & 80.9 \\
\hline 2001 & & & 34018 & 80.8 \\
\hline 2002 & & & 36690 & 81.3 \\
\hline 2003 & & & 38207 & 82.3 \\
\hline 2004 & & & 42042 & 83.3 \\
\hline 2005 & & & 47861 & 84.5 \\
\hline 2006 & 38462 & 85.0 & 54222 & 86.2 \\
\hline 2007 & 47694 & 78.5 & 59464 & 87.2 \\
\hline 2008 & 52428 & 79.8 & 62234 & 88.7 \\
\hline 2009 & 55674 & 84.8 & 74309 & 93.1 \\
\hline 2010 & 48363 & 84.3 & 70590 & 91.7 \\
\hline 2011 & 51252 & 84.9 & 75555 & 91.6 \\
\hline 2012 & 54161 & 85.2 & 89700 & 92.7 \\
\hline 2013 & 62331 & 86.6 & 90950 & 92.7 \\
\hline 2014 & 68200 & 88.0 & 105875 & 93.8 \\
\hline
\end{tabular}

Source: Authors' calculations

\section{The importance of exporters in Latvia and Estonia's economy}

In many countries only a handful of firms export (e.g. Mayer and Ottaviano, 2008). The share of exporters out of all firms tends to be larger in countries with higher GDP per capita (Fernandes et al., 2016). Exports are also often concentrated among the largest exporters. The degree of concentration of exports to a few firms tends to be higher in countries with higher GDP per capita, as more efficient resource allocation allows productive firms to attract more resources and to grow in size (Fernandes et al., 2016).

\section{Exporters are few, particularly in Latvia}

Exporters comprise around 6-8\% of all firms in Latvia, which is considerably lower than in Estonia where around $12 \%$ of all firms exports (Table 2). Exporting is particularly uncommon among firms in nontransport services in Latvia. The lower export participation of firms in Latvia than in Estonia may be partly due to the micro enterprise tax regime introduced in 2011, which applies a flat rate on corporate income taxation and social security contribution. This tax regime is found to have encouraged Latvian firms, especially those in knowledge-intensive service sector, to remain small or split into even smaller units (World Bank, 2017). Because smaller firms are less able to cover the sunk costs associated with export entry, this tax regime may have held back the export entry of Latvian firms. However, as seen in Table 1, the share of small firms out of all firms is higher in Estonia than in Latvia. Also, the share of exporting firms in Latvia is still lower than in Estonia even when focusing on larger firms with more than 10 employees: in 2014, 28\% of large firms exported in Latvia as compared with $42 \%$ in Estonia. The 
difference is more striking for non-transport services where only $1.6 \%$ of Latvian firms with more than 10 employees exported as compared with $24 \%$ of Estonian firms.

The shares of exporters in various types of exports summarised in Table 2 suggests that, Latvia and Estonia differ in their main roles within GVCs. Latvian exporters are mainly goods exporters whereas service exporters are rare. In Estonia, there are as many service exporters as goods exporters. However, it should be noted that goods and service exporters are not mutually exclusive as there are firms that export both goods and services. In Latvia, firms exporting intermediate goods, final goods or engaging in reexports account for about 3\% of all firms, while in Estonia, a larger share of firms are exporting intermediate goods $(4.2 \%)$ than final goods $(2.5 \%)$ or re-exporting $(1.4 \%)$. In Latvia, more than half of service exporters are exporting transport services, reflecting Latvia's role as a provider of logistic services in GVCs (OECD, 2017). In contrast, most of service exporters in Estonia are exporting non-transport services.

\section{Exporters account for a large share of total employment and turnover}

Although exporters are few, exporters account for disproportionally large shares of overall employment and turnover. Exporters' share in total employment is around one-third and in turnover it exceeds 50\% in both Latvia and Estonia (Table 3 and Table 4). Latvian firms engaging in re-exports account for one third in overall turnover, a considerably larger share than that of Estonian re-exporters. The larger share of re-exporters in Latvia than in Estonia indicates the importance of transit trade in the Latvian economy and Latvia's role as the regional hub (Benkoviskis et al., 2016).

Table 2. The share of exporters in the total number of firms (\%)

\begin{tabular}{lrrrr|cccc}
\hline & \multicolumn{4}{c|}{ Latvia } & \multicolumn{4}{c}{ Estonia } \\
\hline & 2006 & 2009 & 2012 & 2014 & 2006 & 2009 & 2012 & 2014 \\
\hline All exporters (goods and services) & 7 & 6.8 & 7.7 & 6.4 & 9.4 & 12.6 & 12.8 & 11.8 \\
Goods exporters & 5.8 & 5.6 & 6.9 & 5.9 & 9.4 & 7.1 & 7.5 & 6.6 \\
Exporters of intermediate inputs & 3 & 2.8 & 3.5 & 3 & 5.7 & 4.5 & 4.7 & 4.2 \\
Exporters of final goods & 2.8 & 2.3 & 3.1 & 2.7 & 3.3 & 2.6 & 2.6 & 2.5 \\
Re-exporters & 2.7 & 3.1 & 3.7 & 3 & 2.2 & 1.6 & 1.6 & 1.4 \\
Services exporters & 1.4 & 1.4 & 1 & 0.7 & NA & 7.1 & 7.1 & 7.1 \\
Transport services exporters & 0.8 & 0.9 & 0.6 & 0.4 & NA & 1.5 & 1.5 & 0.1 \\
Non-transport services exporters & 0.6 & 0.6 & 0.4 & 0.2 & NA & 5.9 & 5.8 & 7.1 \\
\hline
\end{tabular}

Note: For the sake of brevity, only the data in selected years from 2006 is reported.

Source: Authors calculations.

Table 3. The share of exporters in total employment, (\%)

\begin{tabular}{lrrrr|rrrr}
\hline & \multicolumn{4}{c|}{ Latvia } & \multicolumn{4}{c}{ Estonia } \\
\hline & 2006 & 2009 & 2012 & 2014 & 2006 & 2009 & 2012 & 2014 \\
\hline All exporters (goods and services) & 36.2 & 31.5 & 34.5 & 32.4 & 25.6 & 32.5 & 39.8 & 33.6 \\
Goods exporters & 29.4 & 23 & 27.1 & 26 & 25.6 & 17.7 & 23.5 & 19.7 \\
Exporters of intermediate inputs & 15.1 & 11 & 13 & 12.4 & 19.4 & 13.7 & 15.6 & 15.3 \\
Exporters of final goods & 16.5 & 12.7 & 14.2 & 13.7 & 11.9 & 8.4 & 9.9 & 10 \\
Re-exporters & 17.1 & 13.1 & 15.4 & 15.1 & 11.8 & 8.6 & 11.1 & 10.1 \\
Services exporters & 9.9 & 10.3 & 9.6 & 8.4 & NA & 20.2 & 25.7 & 20.8 \\
Transport services exporters & 5.8 & 4.7 & 4.5 & 5.1 & NA & 6 & 7.5 & 1.2 \\
Non-transport services exporters & 4.2 & 4.3 & 4.1 & 3.4 & NA & 16.4 & 21.1 & 20.1 \\
\hline
\end{tabular}

Note: For the sake of brevity, only the data in selected years from 2006 is reported.

Source: Authors calculations. 
Table 4. The share of exporters in total turnover, (\%)

\begin{tabular}{lrrrr|rrrr}
\hline & \multicolumn{4}{c|}{ Latvia } & \multicolumn{4}{c}{ Estonia } \\
\hline & 2006 & 2009 & 2012 & 2014 & 2006 & 2009 & 2012 & 2014 \\
\hline All exporters (goods and services) & 46 & 52.4 & 57.6 & 54.5 & 35.7 & 71.6 & 53.4 & 55.8 \\
Goods exporters & 38.9 & 42.6 & 49.2 & 47.9 & 25.7 & 59.2 & 37.5 & 39 \\
Exporters of intermediate inputs & 16.3 & 17.8 & 20 & 19.7 & 27.3 & 54.1 & 26.6 & 28.9 \\
Exporters of final goods & 13.7 & 21.6 & 21.6 & 20.3 & 14.5 & 10.2 & 15.2 & 17.8 \\
Re-exporters & 29.1 & 30.6 & 34.6 & 35.6 & 21.0 & 12.7 & 22.8 & 25.1 \\
Services exporters & 10.8 & 16.4 & 13.9 & 9.7 & NA & 23.7 & 30.9 & 36.4 \\
Transport services exporters & 6 & 9 & 8 & 6 & NA & 8.6 & 13.1 & 1.9 \\
Non-transport services exporters & 5.4 & 7.6 & 7 & 4.3 & NA & 18.8 & 22.9 & 36.1 \\
\hline
\end{tabular}

Note: For the sake of brevity, only the data in selected years from 2006 onward is reported.

Source: Authors calculations

\section{Exports are concentrated among a few large exporters}

Exports are concentrated among a few large exporters, especially in Estonia. The top-5\% exporters make up nearly $65 \%$ of all Latvian exports and 75\% of all Estonian exports in 2014 (Table 5). In Latvia, the concentration is larger in goods exports than in service exports, while it is the opposite in Estonia. Exports of non-transport services are significantly more concentrated in Estonia than in Latvia, indicating that the largest Latvian exporters of non-transport services are considerably smaller than Estonian exporters.

Table 5. The weight of the top-5\% exporters in total exports, $\%$

\begin{tabular}{lrrrr|rrrr}
\hline & \multicolumn{4}{c}{ Latvia } & \multicolumn{4}{c}{ Estonia } \\
\hline & 2006 & 2009 & 2012 & 2014 & 2006 & 2009 & 2012 & 2014 \\
\hline All exports & 56.9 & 61.5 & 65.7 & 64.5 & 69.6 & 76.5 & 79.1 & 74.6 \\
Goods exports & 58.6 & 62.5 & 68.3 & 66.1 & 69.6 & 69.5 & 74 & 66.9 \\
Exports of intermediate goods & 63.1 & 68.1 & 74.2 & 68.4 & 65.5 & 64.6 & 67.4 & 62.6 \\
Exports of final goods & 55.9 & 60.5 & 68.5 & 68.5 & 68.9 & 63.9 & 73.1 & 64.4 \\
Re-exports & 60.9 & 61.8 & 64.8 & 67.4 & 65.4 & 57.4 & 70 & 56.9 \\
Services exports & 50.3 & 57.9 & 52.7 & 53 & NA & 86.9 & 86.2 & 84.3 \\
Exports of transport services & 51.7 & 63.8 & 58.2 & 59.9 & NA & 76.9 & 82.2 & 50.3 \\
Exports of non-transport services & 39.6 & 36.7 & 30.9 & 37.3 & NA & 86.6 & 77.9 & 85.7 \\
\hline
\end{tabular}

Note: For the sake of brevity, only the data in selected years from 2006 is reported.

Source: Authors calculations

\section{Learning-by-exporting in global value chain}

International trade has long been considered to be a channel of knowledge transfer (Bayoumi et al., 1999; Saggi, 2002). In particular, firms that start exporting are expected to improve productivity by absorbing new knowledge transferred from foreign buyers. Yet, empirical evidences on such productivity gains associated with export entry, often referred to as learning-by-exporting, are mixed at best. Previous studies instead found pervasive evidences on the self-selection of more productive firms into export (for example, Wagner, 2007). Previous studies suggest that learning-by-exporting is far from a general phenomenon, but is conditional on specific circumstances. For instance, supportive evidences are found more in developing countries with potentially larger rooms for technological catch-up (Blalock and 
Gertler, 2004; van Biesebroeck, 2005), or when exports are directed to advanced economies (de Loecker; 2007), or when firms are exporting multiple products to multiple destinations (Masso and Vahter, 2015). This paper explore whether the mixed evidence on learning-by-exporting can be explained by the difference in activities that exporters engage in global value chains (GVCs).

Given the growing importance of global value chains in international trade, it is reasonable to expect that a significant part of exports today are participation in GVC, rather than direct exports to foreign final consumers. In particular, exports of intermediate goods or services are often inputs to GVC that will be embodied in exports by third countries (OECD, 2013). Exports of final goods may also be participation in GVC if it involves an intensive use of imported inputs. For example, the early stage of China's integration to GVCs was mainly driven by the processing trade, where Chinese firms assembled imported parts and components into final products and exported them to final consumption destinations.

GVC is a complex network of interlinked stages of production and non-production activities. It encompasses upstream service activities such as new product design, research and development as well as production activities like manufacturing of key parts and core components; downstream activities such as assembly into final products or transportation and distribution; and far downstream service activities such as marketing/branding and after sales services. Case studies have shown that those activities are known to vary greatly in the size of value added they create (Gerrefi, 1999; Dedrik et al., 2010). New product design or manufacturing of sophisticated components are highly original and they define the competitiveness of the final goods or service produced by the GVC. Such activities are disproportionally well remunerated and comprise a lion's share in the total value added generated by a GVC. On the other hand, standardised and often labour intensive activities like assembly or transport generate relatively small value added, as they are subject to fierce competition which drives down the profit margin.

The essence of the so-called "high-value added activities" is best described by the concept of "bottleneck" put forth by Jacobides et al. (2006). The bottleneck in a value chain is the firm that supplies scarce product or service demanded by numerous buyers, but at the same time can source inputs from numerous suppliers. Due to its strong bargaining power, the firms not only enjoy high profit margin but also appropriates some of the value added originating from the innovation or cost reduction efforts by its buyers and suppliers. This biases the value added generated by a GVC toward few bottleneck firms. The uneven distribution of value added across GVC activities is often described visually as the U-shaped "smile curve," because high-value added activities are often concentrated in the upstream (and far downstream) of GVC.

The scope of learning-by-exporting should depend on which types of activity exporters are engaging in GVCs. More specifically, in order for the export entry to result in a significant and long lasting improvement in productivity, exporters have to participate in high-value added activities in the upstream (or far downstream) of GVC. In case exporters participate in standardised labour-intensive activities in the downstream of GVC, their productivity may increase for a short while thanks to increased capacity utilisation, but such increase is unlikely to be sustained, as some of their productivity gains from learning may be extracted by the bottleneck firms.

Unfortunately, there are not yet established theoretical frameworks that allow mapping a firm's exports into specific GVC activities or inferring the value added a firm can draw from GVC. Antras et al. (2012) propose a measure of "upstreamness", which identifies products that go through numerous production stages before reaching final consumption. However, this measure says little about the scarcity of such products. Costinot et al., (2013) offers a theoretical model on sequential production which provides insights on specialisation within GVC. But the model does not capture the concentration of value added due the uneven bargaining power among participants. Thus, instead of trying to come up with a novel method that maps exporters to specific segments of GVC, this paper simply infers a firm's positon within a 
GVC from the types of goods or services exported. For example, exports of intermediate goods and knowledge intensive services (such as R\&D and ICT services) are often related to activities in the upstream of GVC. The paper thus expects that entry to such exports results in larger productivity gains than entry to exports of final goods or transport services.

For the rest of the paper, the term exporters and GVC participants are used interchangeably, as the paper focuses on GVC participation through exports.

\section{Methodology}

For the main empirical analysis, exports are disaggregated into different types of exports that are highly relevant in the context of GVCs, such as exports of intermediate goods, re-exports, and service export. A firm is considered to be exporting intermediate goods if its exported goods fall into this category according to the OECD BTDIxE end-use classification. This classification is used to compute the bilateral trade flow of intermediate goods across countries, which in turn is used to construct the OECD-WTO Trade in Value Added (TiVA) database, the main workhorse of GVC analysis in global policy discussion fora (OECD, 2013).

Following Benkovskis et al. (2016), a firm is considered to be engaging in re-exports if it imports and exports the same product within an 8-digit Combined Nomenclature (CN code) over the period of 12 months. Re-exports is estimated to account for on average $28 \%$ of Latvian merchandise exports between 2005 and 2013 (Benkovskis et al., 2016). These may not be just logistic services but can also include high value-added activities that mediate trade between parties with large information asymmetries (Feenstra and Hanson, 2004).

The service sector play an increasingly important role in GVCs. Services constitute a large share of the value added created from exports (OECD, 2013). Service inputs increasingly define the competitiveness of manufacturing as they allow firms to add higher value to their products by complementing them with knowledge-intensive services (Miroudot and Cadestin, 2016). This paper distinguishes between transport and non-transport service exporters, given the considerable weights of transport service in Latvian and Estonian exports. Exports of non-transport services include exports of knowledge intensive services such as ICT and professional services whose shares in service exports have been rising recently in both countries.

\section{Observing the premium of GVC participation}

Before proceeding with the formal analysis of the causal relationships between export entry and firm performance, it is useful to compare the average performance of exporters versus non-exporters. This is done by running a pooled OLS regression where firm performance indicators such as productivity, employment and average wage (denoted as $Y_{i j t}$ where subscripts indicate specific firm $i$ in industry $j$ at time $t$ ) are regressed on a dummy variable that takes the value 1 if a firm $i$ is an exporter and 0 otherwise (the term Exporter ${ }_{i j t}$ on the right hand side), while controlling for other factors that affect performance such as firm size, firm age, or foreign ownership (the term $X_{i j t}$ on the right hand side). Industry and year dummies $\eta_{j}$ and $\eta_{t}$ are also included as explanatory variables to control for industry specific and macroeconomic conditions that affect firms' performance.

$$
\ln Y_{i j t}=\alpha+\beta * \text { Exporter }_{i j t}+X_{i j t}+\eta_{j}+\eta_{t}+\varepsilon_{i j t}
$$

The coefficient $\beta$ captures the relative performance of exporting firms versus non-exporters and is often referred to as "exporter's premium". Across countries, this coefficient is found to be positive and 
statistically significant (ISGEP, 2008). In this study, the dummy variable for exporting is replaced by several dummies corresponding to the types of exports related to different stages of GVC participation.

\section{Evaluating the effect of GVC participation}

The paper focuses on the entry into different types of exports. It does not investigate the expansion of incumbent exporters into additional export markets or additional products. The definition of entrants needs to be specified. The most general definition of export entrant would be firms that did not export at time $t-1$ but do so at time $t$. In Latvia, such firms comprise about $20 \%$ of exporters each year and in Estonia close to $50 \%$. However, those entrants include intermittent exporters that exit immediately and thus have very limited opportunities to learn from foreign markets or global buyers. ${ }^{8}$ This paper therefore defines export entrants as firms that did not export in period $t-2$ and $t-1$, started to export in period $t$ and continued exporting in period $t+1 .{ }^{9}$

The effect of export entry can be identified by observing whether firms that started exporting experience a larger gain in productivity level compared to those that did not. However, since export entry (and participation in GVCs) is associated with large sunk costs, only firms with originally higher productivity are likely to become exporters (Melitz, 2003). In order to isolate the effect of exporting from the self-selection of productive firms into exports, the comparison is made between export entrants and the specific group of non-exporters that were initially as likely to start exporting as actual export entrants. This follows the method that has been widely employed by previous studies of learning-by-exporting effect of exports on productivity, possibly channelled by absorption of new knowledge from foreign markets (e.g. De Loecker, 2007).

The first step is to use a pooled Probit model to estimate the probability (propensity score) of each type of export entry (equation 2). The probability for a firm to start exporting (the left hand side of equation 2) is assumed to follow a normal distribution and is the function of its productivity level and other factors that are likely to enable firms to overcome the initial costs of export entry (the vector $\mathrm{X}$ on the right hand side). The control factors include firm size, firm age, the liquidity ratio, capital-to-labour ratio (K/L) and foreign ownership, which are used in earlier studies and also available in the dataset used in this paper.

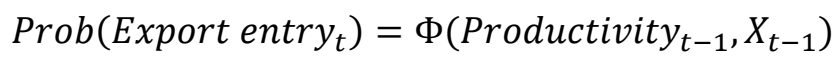

There are a number of other factors such as managerial excellence or innovation-related variables that are likely to drive export entry, but cannot be observed or the data is not available for a large enough sample to incorporate into the calculation of the propensity score of export entry. The explanatory variables of the Probit model are lagged one period before the export entry to ensure that they are unaffected by the entry itself (i.e. to avoid reverse causality). One limitation of this standard analysis is that the the timing of the decision of entry is unobservable and can in fact occur before the actual year of entry. Another limitation is that this framework cannot capture the export entry by firms that start exporting in the year of their creation. ${ }^{10}$

The next step is to match each export entrant with non-exporters with the closest propensity score of export entry. Two nearest neighbours are allocated to each export entrant. The standard condition of

\footnotetext{
${ }^{8}$ Past studies have shown that the share of intermittent export entrants is high. For instance, only $66 \%$ of Estonia's new exporters survive until the second year of exporting (Masso and Vahter 2014, ECB CompNet, 2014).

${ }^{9}$ The paper conducts robustness analysis which employs a wider definition of export entry that includes intermittent exporters.

${ }^{10}$ In Latvia, such firms comprise about $15 \%$ of new exporters.
} 
common support is used when choosing these nearest neighbours. Before calculating the average treatment effects (ATT) of export entry, the study tests whether the treatment group and the constructed control group share similar levels of productivity and other determinants of export entry prior export entry of entrants (the balancing property test of propensity score matching).

Then, mean values of the productivity level $s$ years after the export entry are compared between the group of export entrants (the first term in equation 3) and matched non-exporters (the second term). The difference is interpreted as the effect of export entry.

$$
\text { E(Productivity } \left._{t+s} \mid \text { Export Entry }_{t}=1\right)-E\left(\text { Productivity }_{t+s} \mid \text { Export Entry }_{t}=0\right), s \in(0,2)
$$

\section{The characteristics of GVC participants}

In many countries, exporting firms are more productive and larger than non-exporting firms. This export "premium" is partly explained by the large sunk costs associated with export entry (and participation in GVCs). Only firms that are productive so that they can capture sufficiently large export sales that cover these costs or large enough to enjoy economies of scale enter export (Wagner 2012; Bernard and Jensen, 2004). This section estimates the advantage of exporters against non-exporters in productivity and other measures of performance for various types of exports. It also compares the distributions of productivity between exporters and non-exporters. A large gap between the distributions indicates the existence of a large mass of non-exporters that are too unproductive to participate in GVCs. A large overlap on the other hand suggests a large mass of non-exporters that are productive enough to export but are held back for some reason.

\section{The premium of GVC participants is large, especially in Latvia}

The advantage of exporters against non-exporters in productivity and other performance indicators is observed by estimating equation 1 in the previous section. Table 6 summarises the estimated coefficients $\beta$, which are all statisitically significant at $1 \%$ level. ${ }^{11}$ In both Latvia and Estonia, exporters have higher productivity, hire more employees, pay higher wages and use more capital per worker than non-exporters after controlling for firms' age, liquidity and foreign ownership. This export premium is more pronounced in Latvia than in Estonia. For instance, exporters in Latvia exhibit on average 80\% higher labour productivity and $88 \%$ higher total factor productivity (TFP) than non-exporters, while in Estonia the figures are $61 \%$ and $32 \%$ respectively. Exporter's premium in employment size is also larger in Latvia than in Estonia. This finding corroborates the existence of the large mass of small unproductive non-exporters in Latvia. Non-transport service exporters have particularly large labour productivity premium in both Latvia and Estonia. Firms involved in re-exporting exhibit large productivity premium in Latvia, while this is not the case in Estonia.

\footnotetext{
${ }^{11}$ Coefficients on control variables, which are all statistically significant, are not shown for the sake of brevity.
} 
Table 6. Exporters' premium

ECO/WKP(2017)80

\begin{tabular}{|c|c|c|c|c|c|c|c|c|c|c|}
\hline & \multicolumn{5}{|c|}{ Latvia } & \multicolumn{5}{|c|}{ Estonia } \\
\hline & $\begin{array}{l}\text { Log labour } \\
\text { productivity }\end{array}$ & $\begin{array}{l}\text { Log Total } \\
\text { factor } \\
\text { productivity } \\
\text { (1) }\end{array}$ & $\begin{array}{l}\text { Log } \\
\text { wage }\end{array}$ & $\begin{array}{c}\text { Log } \\
\text { employment }\end{array}$ & $\begin{array}{l}\text { Capital } \\
\text { labour } \\
\text { ratio }\end{array}$ & $\begin{array}{l}\text { Log labour } \\
\text { productivity }\end{array}$ & $\begin{array}{l}\text { Log Total } \\
\text { factor } \\
\text { productivity } \\
\text { (2) }\end{array}$ & $\begin{array}{l}\text { Log } \\
\text { wage }\end{array}$ & $\begin{array}{c}\text { Log } \\
\text { employment }\end{array}$ & $\begin{array}{c}\text { Capital } \\
\text { labour } \\
\text { ratio }\end{array}$ \\
\hline All exporters (goods and services) & $0.802^{\star \star *}$ & $0.881^{* * *}$ & $0.616^{* * *}$ & $1.155^{\star \star *}$ & $0.766^{\star \star *}$ & $0.606^{* * *}$ & $0.321^{* * *}$ & $0.479^{* \star *}$ & $0.328^{* * *}$ & $0.403^{\star \star \star}$ \\
\hline Goods exporters & $0.775^{\star \star \star}$ & $0.858^{* * *}$ & $0.592^{* \star *}$ & $1.100^{* * *}$ & $0.795^{\star \star \star}$ & $0.390^{\star * *}$ & $0.651^{* \star *}$ & $0.243^{\star \star *}$ & $0.946^{\star * *}$ & $0.504^{\star * \star}$ \\
\hline Exporters of intermediate inputs & $0.749^{\star \star \star}$ & $0.876^{\star * \star}$ & $0.604^{\star * *}$ & $1.165^{\star \star \star}$ & $0.754^{* \star *}$ & $0.351^{* \star *}$ & $0.342^{\star \star \star}$ & $0.237^{\star * *}$ & $0.383^{* \star *}$ & $0.480^{\star \star \star}$ \\
\hline Exporters of final goods & $0.712^{\star \star \star}$ & $0.774^{\star * *}$ & $0.532^{\star \star *}$ & $1.092^{* * *}$ & $0.765^{\star \star \star}$ & $0.286^{\star \star \star}$ & $0.291^{\star \star *}$ & $0.398^{\star \star \star}$ & $0.313^{\star \star *}$ & $0.336^{\star * \star}$ \\
\hline Re-exporters & $0.966^{\star \star \star}$ & $1.014^{\star \star *}$ & $0.800^{* * *}$ & $1.336^{\star \star *}$ & $0.901^{* * *}$ & $0.415^{\star \star \star}$ & $0.396^{\star \star \star}$ & $0.263^{\star \star \star}$ & $0.934^{\star \star \star}$ & $0.377^{\star \star \star}$ \\
\hline Services exporters & $0.896^{\star * \star}$ & $0.994^{\star * *}$ & $0.747^{* * *}$ & $1.592^{\star * *}$ & $0.588^{\star \star *}$ & $0.425^{\star \star *}$ & $0.339^{\star * *}$ & $0.642^{\star * *}$ & $1.024^{\star \star *}$ & $0.282^{\star * *}$ \\
\hline Transport services exporters & $0.688^{* * *}$ & $0.945^{* * *}$ & $0.456^{* * *}$ & $1.518^{* * *}$ & $0.817^{\star * *}$ & $0.614^{* * *}$ & $0.522^{\star \star *}$ & $0.165^{\star * *}$ & $1.278^{* * *}$ & $0.574^{\star * *}$ \\
\hline Non-transport services exporters & $1.144^{\star \star \star}$ & $1.023^{\star * *}$ & $1.209^{* * *}$ & $1.698^{\star \star *}$ & $0.210^{* * *}$ & $0.723^{\star \star *}$ & $0.384^{* \star *}$ & $0.339^{* * *}$ & $0.334^{\star * *}$ & $0.345^{\star \star \star}$ \\
\hline
\end{tabular}

Note: ${ }^{* \star *}$ - significant at $1 \% ;{ }^{* *}$ - significant at $5 \%{ }^{*}$ - significant at $1 \%$. Table reports the coefficients from OLS regressions of log values of firm characteristics on export status. All regressions include firm age, foreign ownership dummy, capital region dummy as well as 2-digit NACE sector and year dummies.

(1) Estimated using the method of Galuscak and Lizal (2011).

(2) Estimated using the method of Levinsohn and Petrin (2003).

Source: Authors calculations. 


\section{GVC participants have higher productivity distribution than non-exporters}

Exporters' productivity premium is not only driven by a handful of exporters with very high productivity: exporters are overall more productive than non-exporters. As shown in Figure 1, the productivity distributions (kernel density of the log of labour productivity) of goods exporters and service exporters stochastically dominate the distribution of non-exporters in both Latvia and Estonia. Furthermore, service exporters are overall more productive than goods exporters as their productivity distribution has larger weight on the right-hand side of the distribution than that of goods exporters. ${ }^{12}$

Among goods exporters, the productivity distribution of re-exporters stochastically dominates that of exporters of intermediate and final goods in both countries (Figure 2). Interestingly, the productivity distribution of exporters of intermediate goods is not statistically different from that of exporters of final goods. Among service exporters, the productivity distribution of non-transport service exporters stochastically dominates that of transport service exporters (Figure 3). Furthermore, among Estonian exporters of non-transport services, those exporting knowledge intensive services like R\&D and ICT services have a productivity distribution that stochastically dominates the distribution of other less knowledge intensive services (such as tourism).

Figure 1. Labour productivity distribution of exporters versus non-exporters

Panel A: Latvia

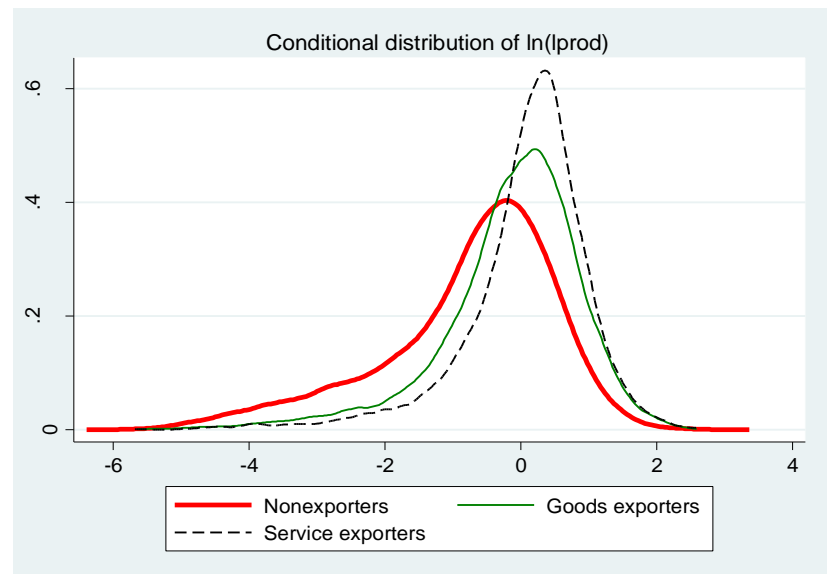

Panel B: Estonia

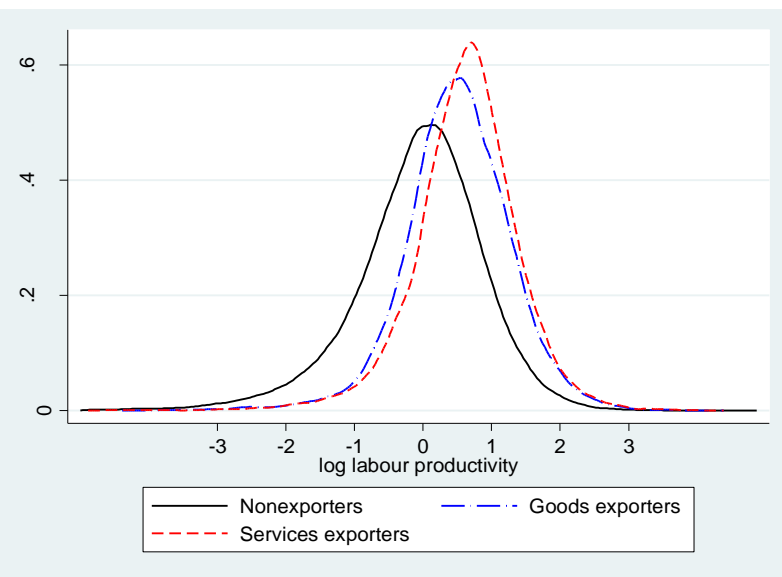

Note: Labour productivity relative to averages of 2-digit NACE sectors.

Source: Authors calculations.

${ }^{12}$ These differences in productivity distributions are confirmed by the results of the Kolmogorov-Smirnov test (available upon requests). 
Figure 2. Labour productivity distribution of goods exporters versus non-exporters

Panel A: Latvia

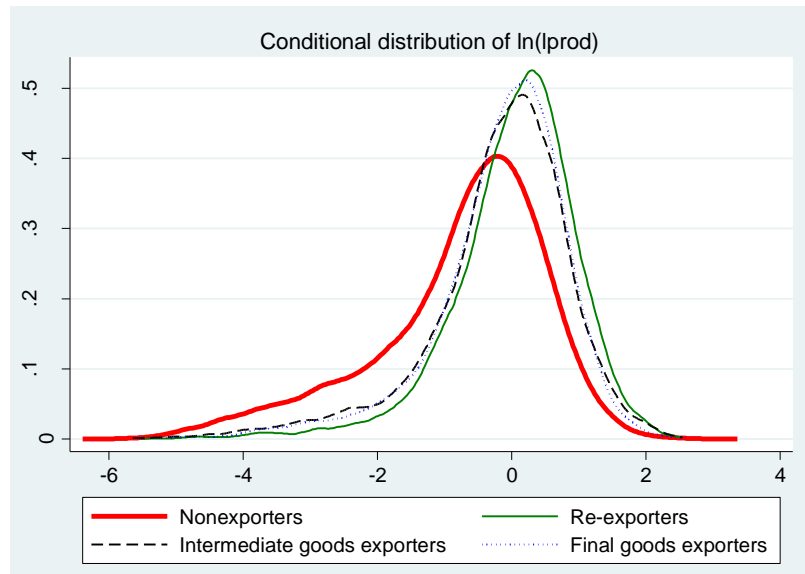

Panel B: Estonia

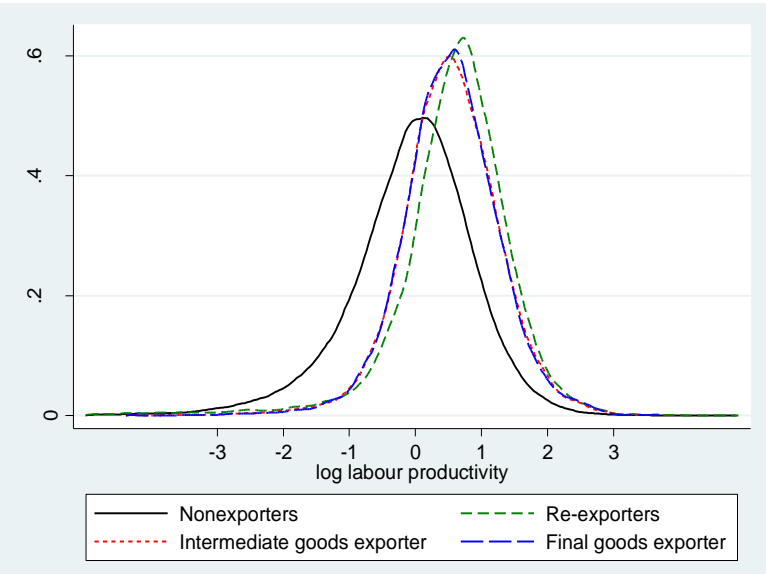

Note: Labour productivity relative to averages of 2-digit NACE sectors.

Source: Authors calculations.

Figure 3. Labour productivity distribution of service exporters versus non-exporters

Panel A: Latvia

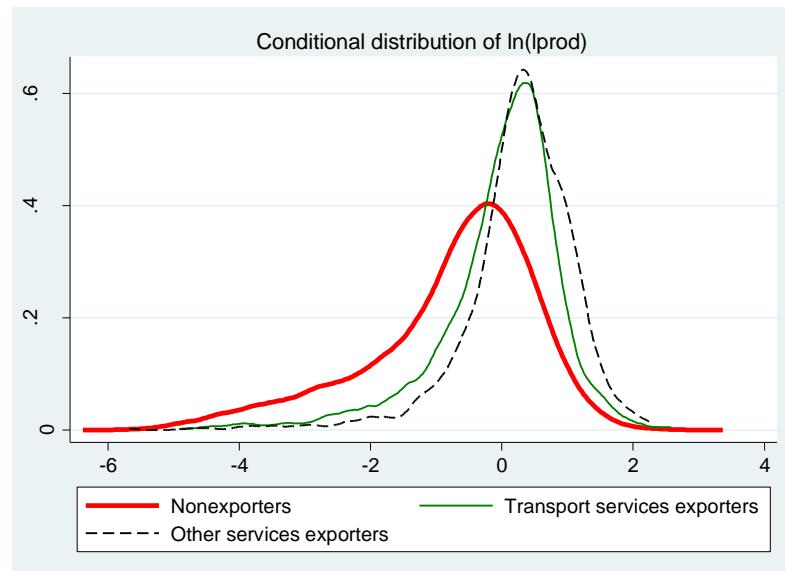

Panel B: Estonia

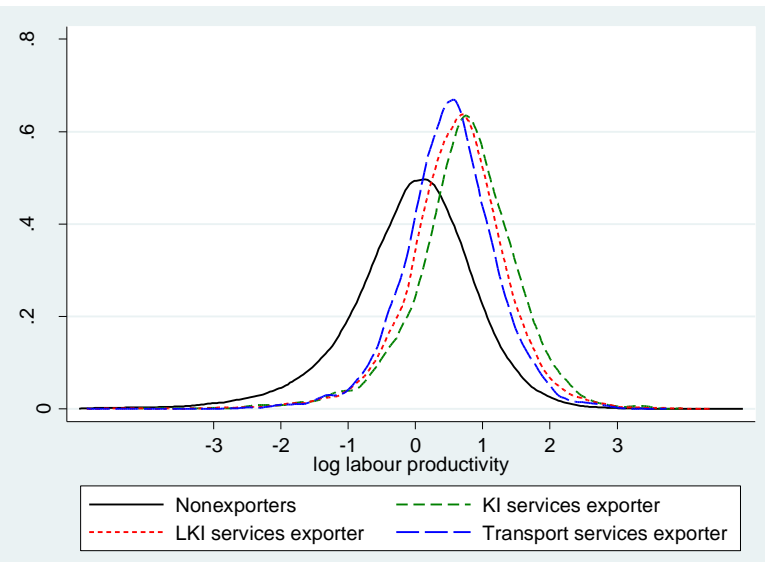

Note: log labour productivity relative to averages of 2-digit NACE sectors.

Source: Authors calculations.

\section{There are many firms that are too unproductive to enter export markets}

The sizable gap between the productivity distributions of exporters and non-exporters indicates a large number of firms that cannot access foreign markets or participate in GVC because of their low productivity. These firms represent a concern for small open economies like Latvia or Estonia, where intensive participation in GVC could boost productivity growth by allowing more firms to exploit scale economy and absorb advanced technologies. To give a perspective of the mass of least productive nonexporters, the share of non-exporters with productivity level below the $10^{\text {th }}$ percentile of the productivity distribution of exporters is reported (the left hand side of Table 7).

In both Latvia and Estonia, this share exceeds 30\% indicating that non-exporters are disproportionally concentrated in the lower part of the productivity distribution. In Latvia, this share has been over $40 \%$ prior to the financial crisis and seems to have declined more recently. In contrast, in Estonia it was close to $32 \%$ 
prior to the crisis but has increased since. Also, such share is significantly smaller in both countries when excluding firms with less than 10 employees. This underscores the existence of many small unproductive firms that do not export. In Estonia, the share has been rather stable in manufacturing sector, indicating that the recent productivity divergence between exporters and non-exporters is occurring mostly in the service sector, where the lack of internationalisation is increasingly recognised as the major impediment to firm's growth.

\section{Many productive firms are held back from entering export markets}

The large overlap between the productivity distributions of exporters and non-exporters can be caused by resource misallocation that prevents productive firms from entering exporting or participating in GVC. ${ }^{13}$ For instance, poor access to credit makes it difficult for productive firms to enter exports if they have to finance entry costs upfront (Chaney, 2016). Shortages of skilled workers with knowledge of foreign markets can also hold back export entry (Masso et al., 2015; Masso and Vahter, 2016). To give an idea about the extent of such overlaps, the share of non-exporters with labour productivity level higher than the median productivity of exporters (e.g. non-exporters that are more productive than the median exporter) is reported (the right hand side of Table 7). In recent years, this share has been around 15\% in Latvia while it remained over $20 \%$ in Estonia. The shares of non-exporters with above median productivity of exporters have come down since 2006, which suggests that resource allocation have improved in both countries. The shares are higher when excluding smaller firms in both countries. This suggests that resource misallocation is mostly holding back larger firms, which are a priori more likely to be exporters.

Table 7. The gap and overlap in the productivity distributions of exporters and non-exporters, $\%$

\begin{tabular}{|c|c|c|c|c|c|c|c|c|}
\hline & \multicolumn{4}{|c|}{$\begin{array}{c}\text { The share of non-exporters with labour productivity } \\
\text { below the } 10^{\text {th }} \text { percentile of exporters' productivity } \\
\text { distribution }\end{array}$} & \multicolumn{4}{|c|}{$\begin{array}{c}\text { The share of non-exporters with labour productivity } \\
\text { above the median of exporters' productivity } \\
\text { distribution }\end{array}$} \\
\hline & \multicolumn{2}{|c|}{ Latvia } & \multicolumn{2}{|c|}{ Estonia } & \multicolumn{2}{|c|}{ Latvia } & \multicolumn{2}{|c|}{ Estonia } \\
\hline & All firms & $\begin{array}{l}\text { Firms with } \\
10 \text { or more } \\
\text { employees }\end{array}$ & All firms & $\begin{array}{l}\text { Firms with } \\
10 \text { or more } \\
\text { employees }\end{array}$ & All firms & $\begin{array}{l}\text { Firms with } \\
10 \text { or more } \\
\text { employees }\end{array}$ & All firms & $\begin{array}{l}\text { Firms with } \\
10 \text { or more } \\
\text { employees }\end{array}$ \\
\hline 2006 & 45.1 & 22.8 & 31.8 & 24.3 & 19.3 & 29.6 & 24.8 & 31.8 \\
\hline 2007 & 44.9 & 39.9 & 33 & 23.3 & 16.6 & 19.2 & 23.1 & 29.6 \\
\hline 2008 & 43.6 & 33.3 & 32.8 & 25.4 & 17.4 & 21.3 & 21.8 & 27 \\
\hline 2009 & 40.1 & 25.4 & 36 & 28.5 & 18.5 & 23.4 & 24.2 & 30.4 \\
\hline 2010 & 43 & 34 & 36.4 & 26.6 & 18.2 & 19.8 & 20.9 & 26.8 \\
\hline 2011 & 37.2 & 32.4 & 35.1 & 23.7 & 16.4 & 19.9 & 21.5 & 29.1 \\
\hline 2012 & 31 & 31.1 & 35.4 & 22.5 & 15.4 & 19.7 & 22.2 & 28.8 \\
\hline 2013 & 39.1 & 28.1 & 36.1 & 21.6 & 16.5 & 20 & 21.3 & 28.9 \\
\hline 2014 & 31.1 & 25.2 & 36.7 & 25.9 & 14.3 & 21.8 & 21.1 & 25.9 \\
\hline
\end{tabular}

Source: Authors calculations.

\footnotetext{
${ }^{13}$ The large overlaps in productivity distributions of exporters and non-exporters can also occur if entry costs of exports vary greatly across sectors and exporters are concentrated in sectors with low entry costs while non-exporters are concentrated in sectors with high entry costs. However, there are not a priori reasons to think this is the case. It is also possible that some productive non-exporters are in fact participating in GVCs through other channels than exports, such as supplying the local branches of multinational enterprises.
} 


\section{Determinants of GVC participation}

Having observed the large and statistically significant premium of GVC participants, the next step is to assess whether such an advantage attributes to the self-selection of most productive firms into exporting, or whether firms become more productive as a result of their exposure to the global market. These two explanations are not mutually exclusive as both self-selection and learning-by-exporting can both contribute to the outperformance of exporters over non-exporters.

Table 8 displays the estimation results of the Probit regressions for Latvia (Panel A) and Estonia (Panel B). The explanatory variables included labour productivity, employment size and age (as well as their non-linear components), liquidity ratio, capital to labour ratio. Year and NACE 2-digit sector fixed effects were also included to control for the macroeconomic environment and industry specific conditions. In the case of Latvia, two dummies for foreign ownership (distinguishing between owners from OECD and non-OECD countries) are included to capture possible knowledge spillovers from multinational enterprises, while for Estonia a dummy variable indicating that the firm is foreign-owned and another dummy variable indicating that the firms is located in Northern Estonia (Tallinn and Harju country, the wider capital region) are included.

Probit estimation results give a clear indication of self-selection of productive firms into all types of exports, as higher labour productivity increases the probability of all types of export entry in both countries. Firm size is also observed to increase the probability of export entry, suggesting the importance of economy of scale in covering the entry costs to exports. Higher capital to labour ratio is also associated with higher probability of export entry except in that of non-transport services. Furthermore, in both countries older firms are associated with lower probability of export entry. But beyond a certain age (17 years for Latvian firms) the likelihood of export entry increases, as shown by the positive and statistically significant sign on the quadratic age term.

An interesting difference emerges between the two countries on the effect of cash flow on export entry. In Estonia, higher liquidity ratio is associated with higher probability of export entry, as expected from theories on the extensive margin of trade under credit constraints (Muûls, 2015). However, in Latvia a lower liquidity ratio in the previous period is associated with a higher probability of export entry. The negative relation is robust to different lags and is a puzzle. One possible explanation is that stronger credit constraints motivate Latvian firms to enter export to increase cash flow. Exporting may also improve access to credit by acting as a signal of regionally diversified revenue sources (Shaver, 2011).

The foreign ownership from an OECD country is only significantly associated with a higher probability of entry into service exports by Latvian firms, in particular into transport service exports. Foreign ownership is significantly associated with higher probability of entry into all types of exports by Estonian firms, with particularly strong effect in the case of services exports. Location of a firm in Northern Estonia is associated with higher probability of entry into goods exports but not service exports, possibly indicating the relevance of proximity to the ports and industrial agglomeration in those exports. 
Table 8. Probit estimation of the probability of export entry

A. Latvia

\begin{tabular}{|c|c|c|c|c|c|c|c|c|}
\hline & \multirow[b]{2}{*}{ All exports } & \multicolumn{2}{|c|}{ Type } & \multicolumn{5}{|c|}{ Participation in GVCs } \\
\hline & & $\begin{array}{l}\text { Exports of } \\
\text { goods }\end{array}$ & $\begin{array}{l}\text { Exports of } \\
\text { services }\end{array}$ & $\begin{array}{l}\text { Exports of } \\
\text { intermediate } \\
\text { products }\end{array}$ & $\begin{array}{l}\text { Exports of } \\
\text { final use } \\
\text { products }\end{array}$ & Re-exports & $\begin{array}{l}\text { Exports of } \\
\text { transport } \\
\text { services }\end{array}$ & $\begin{array}{l}\text { Exports of } \\
\text { other } \\
\text { services }\end{array}$ \\
\hline $\log (\text { labour productivity })_{\mathrm{t}-1}$ & $0.188 * * *$ & $0.171 * * *$ & $0.371 * * *$ & $0.110 * * *$ & $0.206^{* * *}$ & $0.297 * * *$ & $0.185 * * *$ & $0.608 * * *$ \\
\hline $\log (\text { employment })_{t-1}$ & $0.368 * * *$ & $0.309 * * *$ & $0.884 * * *$ & $0.393 * * *$ & $0.340 * * *$ & $0.401 * * *$ & $1.180 * * *$ & $0.575 * * *$ \\
\hline $\log (\text { employment })_{\mathrm{t}-1}{ }^{2}$ & $-0.021 * * *$ & $-0.011^{*}$ & $-0.082 * * *$ & $-0.024 * * *$ & -0.012 & $-0.019 * *$ & $-0.123 * * *$ & -0.027 \\
\hline $\mathrm{Age}_{\mathrm{t}-1}$ & $-0.068 * * *$ & $-0.058 * * *$ & $-0.088 * * *$ & $-0.078 * * *$ & $-0.041 * *$ & $-0.062 * * *$ & $-0.089 * *$ & $-0.083 *$ \\
\hline $\mathrm{Age}_{\mathrm{t}-1}{ }^{2}$ & $0.002 * * *$ & $0.002 * *$ & $0.003^{*}$ & $0.003 * * *$ & 0.001 & $0.002 *$ & $0.004^{*}$ & 0.001 \\
\hline Liquidity ratio $_{\mathrm{t}-1}$ & $-0.377 * * *$ & $-0.421 * * *$ & -0.220 & $-0.638 * * *$ & $-0.514 * * *$ & $-0.497 * * *$ & -0.232 & -0.187 \\
\hline Capital to labour ratio t -1 & $0.078 * * *$ & $0.080 * * *$ & $0.071 * *$ & $0.081 * * *$ & $0.085^{* * * *}$ & $0.068 * * *$ & $0.198 * * *$ & -0.053 \\
\hline $\begin{array}{l}\text { Foreign ownership dummy } \\
\text { (owner from } \text { OECD }_{\mathrm{t}-1} \\
\text { country) }\end{array}$ & 0.151 & 0.124 & $0.436 * * *$ & 0.008 & $0.387 * * *$ & 0.033 & $0.627 * * *$ & 0.231 \\
\hline $\begin{array}{l}\text { Foreign ownership dummy } \\
\text { (owner from non-OECD } \\
\text { country) }\end{array}$ & 0.019 & -0.125 & 0.348 & 0.076 & 0.146 & -0.147 & 0.487 & -0.248 \\
\hline Log-likelihood & -3769.4 & -3482.6 & -597.3 & -2028.4 & -2226.8 & -2192.3 & -332.0 & -249.3 \\
\hline Number of observations & 50612 & 50020 & 24539 & 45931 & 48366 & 43259 & 11676 & 21828 \\
\hline pseudo $\mathrm{R}^{2}$ & 0.19 & 0.20 & 0.32 & 0.21 & 0.23 & 0.25 & 0.35 & 0.36 \\
\hline
\end{tabular}

\section{B.Estonia}

\begin{tabular}{|c|c|c|c|c|c|c|c|c|}
\hline & \multirow[b]{2}{*}{ All exports } & \multicolumn{2}{|c|}{ Type } & \multicolumn{5}{|c|}{ Participation in GVCs } \\
\hline & & $\begin{array}{l}\text { Exports of } \\
\text { goods }\end{array}$ & $\begin{array}{c}\text { Exports of } \\
\text { services }\end{array}$ & $\begin{array}{c}\text { Exports of } \\
\text { intermediate } \\
\text { products }\end{array}$ & $\begin{array}{l}\text { Exports of } \\
\text { final use } \\
\text { products }\end{array}$ & Re-exports & $\begin{array}{c}\text { Exports of } \\
\text { transport } \\
\text { services }\end{array}$ & $\begin{array}{c}\text { Exports of } \\
\text { other } \\
\text { services }\end{array}$ \\
\hline Log(labour productivity) $)_{\mathrm{t}-1}$ & $0.234 * * *$ & $0.213 * * *$ & $0.287 * * *$ & $0.236 * * *$ & $0.226 * * *$ & $0.401 * * *$ & $0.195 * * *$ & $0.304 * * *$ \\
\hline $\log (\text { employment })_{\mathrm{t}-1}$ & $0.292 * * *$ & $0.264 * * *$ & $0.342 * * *$ & $0.214 * * *$ & $0.237 * * *$ & $0.258 * * *$ & $0.604 * * *$ & $0.245^{* * *} *$ \\
\hline $\log (\text { employment })_{t-1}{ }^{2}$ & $-0.011 * *$ & -0.004 & -0.004 & 0.002 & -0.009 & -0.002 & $-0.043 * *$ & 0.01 \\
\hline $\operatorname{Age}_{\mathrm{t}-1}$ & $-0.217 * * *$ & $-0.274 * * *$ & $-0.350 * * *$ & $-0.251 * * *$ & $-0.170 * *$ & $-0.375 * * *$ & $-0.340 * *$ & $-0.339 * * *$ \\
\hline $\operatorname{Age}_{\mathrm{t}-1}{ }^{2}$ & $0.021 *$ & $0.055 * * *$ & 0.023 & $0.039 * *$ & 0.026 & $0.085^{* * * *}$ & 0.032 & 0.019 \\
\hline Liquidity ratio ${ }_{\mathrm{t}-1}$ & $0.094 * * *$ & $0.114 * * *$ & 0.072 & $0.081 * * *$ & $0.157 * * *$ & $0.139 * * *$ & 0.148 & 0.06 \\
\hline Capital to labour ratio ${ }_{t-1}$ & $0.040 * * *$ & $0.061 * * *$ & $0.034 * * *$ & $0.032 * * *$ & $0.023 * *$ & $0.024 * *$ & $0.118 * * *$ & 0.011 \\
\hline Foreign firm dummy & $0.362 * * *$ & $0.296 * * *$ & $0.688 * * *$ & $0.338 * * *$ & $0.333 * * *$ & $0.356 * * *$ & $0.649 * * *$ & $0.714 * * *$ \\
\hline Northern Estonia dummy & $0.117 * * *$ & $0.148 * * *$ & 0.015 & $0.144 * * *$ & $0.280 * * *$ & $0.222 * * *$ & -0.009 & 0.031 \\
\hline Log-likelihood & -18610.3 & -14820.7 & -3677.34 & -8114.04 & -5014.22 & -5085.18 & -1082.51 & -2879.06 \\
\hline Number of observations & 100456 & 99168 & 30516 & 96188 & 93792 & 94051 & 23687 & 28563 \\
\hline pseudo $\mathrm{R}^{2}$ & 0.122 & 0.143 & 0.184 & 0.17 & 0.175 & 0.229 & 0.32 & 0.184 \\
\hline
\end{tabular}

Note: *significant at $10 \%$; ${ }^{* *}$ significant at $5 \%$; ${ }^{* *}$ significant at $1 \%$.

Source: Authors calculations.

The estimated coefficients of the Probit regressions are used to calculate the propensity score of all firms, which is used in the next section to create the counterfactual control groups of non-entrants that share similar characteristics as the actual entrants.

While productivity is the main determinant of export entry, the existence of large number of nonexporters that are as productive as exporters indicate that there are also other significant determinants. 
Identifying what these factors are provides rich policy implications. For example, the analysis in Appendix 1 shows that hiring more employees and managers with experience of working for exporting firms and MNEs facilitates export entry by Estonian firms. Also, the skill intensity of Estonian exporters is found to be higher than that of non-exporters: the employment structure of exporters is biased towards professionals and skilled employees. Those findings underscore the importance of skills for more intensive participation in GVC.

\section{The effect of GVC participation}

This section assesses the causal effect of various types of export entry using the conventional framework of propensity score matching. Each entrant is matched with two firms that have never exported during the time period from $\mathrm{t}-2$ to $\mathrm{t}+1$ and have closest propensity score as the entrant. The balancing property test of pre-treatment differences between the treated (export entrants) and control group (matched non-entrants) is used to infer the quality of matching. Table 9 reports the results of the balancing property test for all exporters, as an example. The $\mathrm{t}$ statistics and p-values after the propensity score matching indicate that the procedure eliminated statistically significant differences in the determinants of export entry $^{14}$. Therefore, the control group constructed by the matching can be regarded as the counterfactual for export entrants, in case they did not enter exports markets.

Following the equation 3, the average treatment effect on treated firms? (ATT) is computed as the average difference in productivity and other measures of performance between export entrants and control group for up to three years after the export entry (Table 10). Overall, export entry results in a significant boost in the productivity level that is long lasting in both Latvia and Estonia. Export entry raises labour productivity of Latvian firms by $23 \%$ in the year of entry and by $20 \%$ in the third year whereas the respective figures for Estonian firms are 14\% and 13.5\% (the first column of Table 10).

The effect of export entry differs across types of exports. Entries into exports of intermediate goods and non-transport services (which include knowledge intensive services) are associated with significant gains in productivity level in both Latvia and Estonia. Entry into re-exports is also associated with sizable improvement in the productivity level in both countries, indicating that re-exports are high value added activities that may go beyond simple logistic services. ${ }^{15}$

\footnotetext{
${ }^{14}$ This approach is based on the standard and potentially rather limiting assumption that the researcher observes the relevant drivers of export entry decision.

${ }^{15}$ The profit margin of re-exports is indeed large and has important contribution to Latvian economy (Benkovskis et al., 2016).
} 
Table 9. Mean values of main determinants of export entry before and after matching

A. Latvia

\begin{tabular}{|c|c|c|c|c|c|c|}
\hline & & $\begin{array}{l}\text { Mean of } \\
\text { treated }\end{array}$ & $\begin{array}{c}\text { Mean of } \\
\text { control }\end{array}$ & $\begin{array}{c}\text { Difference } \\
\quad(\%)\end{array}$ & t-statistics & $\mathrm{p}$-value \\
\hline \multirow[t]{2}{*}{$\log (\text { labour productivity })_{t-1}$} & Unmatched & 2.291 & 1.606 & 60.0 & 17.41 & 0.000 \\
\hline & Matched & 2.292 & 2.289 & 0.2 & 0.05 & 0.959 \\
\hline \multirow[t]{2}{*}{$\log (\text { employment })_{\mathrm{t}-1}$} & Unmatched & 2.466 & 1.649 & 65.0 & 21.17 & 0.000 \\
\hline & Matched & 2.466 & 2.431 & 2.8 & 0.57 & 0.567 \\
\hline \multirow[t]{2}{*}{$\operatorname{Age}_{t-1}$} & Unmatched & 8.593 & 9.150 & -10.5 & -3.17 & 0.002 \\
\hline & Matched & 8.603 & 8.703 & -1.9 & -0.41 & 0.684 \\
\hline \multirow[t]{2}{*}{ Liquidity ratio ${ }_{\mathrm{t}-1}$} & Unmatched & 0.098 & 0.147 & -29.2 & -7.71 & 0.000 \\
\hline & Matched & 0.098 & 0.101 & -1.6 & -0.42 & 0.676 \\
\hline \multirow[t]{2}{*}{ Capital to labour ratio ${ }_{t-1}$} & Unmatched & 2.009 & 1.276 & 42.6 & 11.65 & 0.000 \\
\hline & Matched & 2.011 & 1.981 & 1.8 & 0.43 & 0.667 \\
\hline \multirow{2}{*}{$\begin{array}{l}\text { Foreign ownership dummy (owner } \\
\text { from } \mathrm{OECD}_{\mathrm{t}-1} \text { country) }\end{array}$} & Unmatched & 0.040 & 0.008 & 20.3 & 9.85 & 0.000 \\
\hline & Matched & 0.040 & 0.0 .035 & 3.2 & 0.55 & 0.582 \\
\hline \multirow{2}{*}{$\begin{array}{l}\text { Foreign ownership dummy (owner } \\
\text { from non-OECD } D_{t-1} \text { country) }\end{array}$} & Unmatched & 0.012 & 0.004 & 9.0 & 3.82 & 0.000 \\
\hline & Matched & 0.012 & 0.011 & 0.6 & 0.11 & 0.914 \\
\hline
\end{tabular}

B. Estonia

\begin{tabular}{|c|c|c|c|c|c|c|}
\hline & & $\begin{array}{l}\text { Mean of } \\
\text { treated }\end{array}$ & $\begin{array}{c}\text { Mean of } \\
\text { control }\end{array}$ & $\begin{array}{c}\text { Difference } \\
(\%)\end{array}$ & t-statistics & p-value \\
\hline \multirow[t]{2}{*}{$\log (\text { labour productivity })_{\mathrm{t}-1}$} & Unmatched & 9.94 & 9.53 & 48.3 & 28.84 & 0.00 \\
\hline & Matched & 9.94 & 9.93 & 0.9 & 0.39 & 0.70 \\
\hline \multirow[t]{2}{*}{$\log (\text { employment })_{t-1}$} & Unmatched & 2.09 & 1.69 & 38.3 & 23.42 & 0.00 \\
\hline & Matched & 2.09 & 2.09 & 0.4 & 0.18 & 0.86 \\
\hline \multirow[t]{2}{*}{$\mathrm{Age}_{\mathrm{t}-1}$} & Unmatched & 1.79 & 1.85 & -8.3 & -5.06 & 0.00 \\
\hline & Matched & 1.79 & 1.8 & -1.1 & -0.47 & 0.64 \\
\hline \multirow[t]{2}{*}{ Liquidity ratio $_{\mathrm{t}-1}$} & Unmatched & 0.57 & 0.53 & 10.3 & 6.38 & 0.00 \\
\hline & Matched & 0.57 & 0.56 & 1.2 & 0.53 & 0.60 \\
\hline \multirow[t]{2}{*}{ Capital to labour ratio ${ }_{t-1}$} & Unmatched & 8.56 & 8.21 & 22.8 & 13.64 & 0.00 \\
\hline & Matched & 8.56 & 8.57 & -0.7 & -0.33 & 0.74 \\
\hline \multirow[t]{2}{*}{ Foreign firm ${ }_{t-1}$} & Unmatched & 0.11 & 0.03 & 30.2 & 24.37 & 0.00 \\
\hline & Matched & 0.11 & 0.11 & -0.2 & -0.05 & 0.96 \\
\hline \multirow[t]{2}{*}{ Northern Estonia ${ }_{t-1}$} & Unmatched & 0.51 & 0.4 & 22 & 13.3 & 0.00 \\
\hline & Matched & 0.51 & 0.52 & -1.4 & -0.61 & 0.54 \\
\hline
\end{tabular}

Source: Authors calculations.

Productivity gains from entry into exports of final goods or exports of transport services are less clear. In the context of GVC, they are associated with assembly into final products and logistic services, which are often characterised by standardised processes and strong competition pressure, thereby resulting in low profit margins (OECD, 2013). For Latvian firms, labour productivity gains from entry into such exports are 
smaller or statistically insignificant, even though it boosts turnover per worker. However, for Estonian firms, these entries results in significant gains in productivity comparable to entries in exports of intermediate goods or non-transport services. The difference in the productivity effect between the two countries could be driven by several factors. For instance, while $57 \%$ of Estonia's exports of final goods are directed to OECD countries other than Latvia, 30\% of Latvia's exports of final goods are directed to OECD countries other than Estonia. ${ }^{16}$ The higher share of exports to advanced economies may have encouraged final goods exporters in Estonia to upgrade product quality or allowed them to enjoy larger learning-by-exporting. ${ }^{17}$ Also, Estonia's transport services may be more oriented toward passenger transports which have little to do with GVC participation, whereas Latvia's transport services are primarily freight. ${ }^{18}$

The estimated gains in labour productivity are often the strongest in the year of export entry and level off thereafter (notable exceptions are entry to re-exports by Latvian firms and to exports of transport services by Estonian firms). ${ }^{19}$ One possible explanation is that learning-by-exporting occurs quickly because export entrants have very low initial knowledge-base. ${ }^{20}$ An alternative interpretation is that the productivity gains are driven mostly by an increase in capacity utilisation as firms enjoy larger demand, rather than absorption of new knowledge or innovation. Appendix 2 shows for Estonian firms that, exporting is significantly correlated with higher probability of realising various kinds of innovation. However, this correlation becomes statistically insignificant once major inputs to innovation such as R\&D or knowledge sourcing activities are taken into account.

Export entry significantly increases employment, indicating that the increase in labour productivity following export entry is not driven by shedding employment. Instead, an access to larger markets seems to be allowing Latvian and Estonian firms to hire more. Significant increase in employment follows entries to exports of intermediate goods, re-exports in both countries and exports of non-transport services in Estonia. But it is less clear or weaker in the case of exports of final goods or transport services. Furthermore, export entry also results in firms paying higher wages. But this is only the case for entry to exports of intermediate goods, re-exports and exports of non-transport services. In Latvia, entry to transport services actually results in a significant decline in average wage. Overall, participation in upstream of GVC is more likely to increase high quality jobs in both countries. Lastly, export entry increases the capital intensity of Latvian firms entering goods exports but not that of Estonian firms.

\footnotetext{
${ }^{16}$ Figures are from the latest available year.

${ }^{17}$ For instance, de Loecker (2007) reported for Slovenian firms that learning-from-exporting is primarily found in case of exports to OECD countries.

${ }^{18}$ In 2014, 49\% of turnover in Latvia's transport service sector occurred in freight.

${ }^{19}$ Total factor productivity of Estonian firms is not significant in the period of entry, but turns positive and significant in post-treatment periods, starting from $\mathrm{t}+1$.

${ }^{20}$ For instance, the business-based R\&D (BERD) expenditure in Latvia and Estonia amounted to $0.15 \%$ and $0.7 \%$ of GDP respectively in 2015. Such R\&D intensities underperform the OECD average of 1.64\% (OECD, 2017).
} 
Table 10. The effect of export entry on productivity and other measures of performance

\section{A. Latvia}

\begin{tabular}{|c|c|c|c|c|c|c|c|c|c|}
\hline & & \multirow[b]{2}{*}{$\begin{array}{c}\text { All } \\
\text { exports }\end{array}$} & \multicolumn{2}{|c|}{ Type } & \multicolumn{5}{|c|}{ Participation in GVCs } \\
\hline & & & $\begin{array}{l}\text { Exports of } \\
\text { goods }\end{array}$ & $\begin{array}{l}\text { Exports } \\
\text { of } \\
\text { services }\end{array}$ & $\begin{array}{c}\text { Exports of } \\
\text { intermediat } \\
\text { e products }\end{array}$ & $\begin{array}{c}\text { Exports } \\
\text { of final } \\
\text { use } \\
\text { nroducts }\end{array}$ & $\begin{array}{c}\text { Re- } \\
\text { exports }\end{array}$ & $\begin{array}{c}\text { Exports of } \\
\text { transport } \\
\text { services }\end{array}$ & $\begin{array}{c}\text { Exports of } \\
\text { other } \\
\text { services }\end{array}$ \\
\hline Labour & $\mathrm{T}$ & $0.232 * * *$ & $0.259 * * *$ & 0.147 & $0.270 * * *$ & 0.121 & $0.237 * * *$ & -0.022 & $0.324 * *$ \\
\hline \multirow[t]{2}{*}{ Productivity } & $t+1$ & $0.195 * * *$ & $0.205 * * *$ & 0.118 & $0.207 * *$ & 0.129 & $0.287 * * *$ & 0.017 & 0.190 \\
\hline & $t+2$ & $0.199 * * *$ & $0.225 * * *$ & $0.279 * *$ & $0.218 * * *$ & $0.177 * *$ & $0.392 * * *$ & 0.191 & 0.100 \\
\hline \multirow{3}{*}{$\begin{array}{l}\text { Total Factor } \\
\text { Productivity(1 }\end{array}$} & $\mathrm{T}$ & $0.268 * * *$ & $0.281 * * *$ & $0.215^{*}$ & $0.288 * * *$ & 0.087 & $0.252 * * *$ & -0.015 & $0.398 * * *$ \\
\hline & $t+1$ & $0.231 * * *$ & $0.229 * * *$ & $0.203 *$ & $0.252 * * *$ & 0.084 & $0.288 * * *$ & 0.032 & 0.258 \\
\hline & $t+2$ & $0.239 * * *$ & $0.250 * * *$ & $0.344 * * *$ & $0.269 * * *$ & $0.139 *$ & $0.382 * * *$ & 0.185 & 0.172 \\
\hline \multirow{3}{*}{$\begin{array}{l}\text { Turnover per } \\
\text { Worker }\end{array}$} & $\mathrm{T}$ & $0.496^{* * *}$ & $0.479 * * *$ & $0.341 * * *$ & $0.534 * * *$ & $0.299 * * *$ & $0.572 * * *$ & $0.319 * * *$ & $0.327 * *$ \\
\hline & $t+1$ & $0.491 * * *$ & $0.481 * * *$ & $0.306^{* * *}$ & $0.562 * * *$ & $0.354 * * *$ & $0.603 * * *$ & $0.343 * * *$ & 0.219 \\
\hline & $t+2$ & $0.448 * * *$ & $0.451 * * *$ & $0.343 * * *$ & $0.502 * * *$ & $0.365 * * *$ & $0.569 * * *$ & $0.369 * * *$ & $0.235^{*}$ \\
\hline \multirow{3}{*}{$\begin{array}{l}\text { Number of } \\
\text { Employees }\end{array}$} & $\mathrm{T}$ & $0.137 * * *$ & $0.105 * * *$ & $0.309 * * *$ & $0.130 * * *$ & 0.056 & $0.125^{* * *}$ & 0.217 & 0.230 \\
\hline & $t+1$ & $0.187 * * *$ & $0.158 * * *$ & $0.401 * * *$ & $0.204 * * *$ & 0.045 & $0.149 * * *$ & $0.242 *$ & 0.300 \\
\hline & $t+2$ & $0.214 * * *$ & $0.184 * * *$ & $0.401 * * *$ & $0.256 * * *$ & 0.037 & $0.161 * * *$ & 0.212 & 0.353 \\
\hline \multirow[t]{3}{*}{ Average wage } & $\mathrm{T}$ & 0.040 & 0.038 & -0.001 & -0.006 & -0.028 & 0.045 & $-0.220 * *$ & $0.218 * *$ \\
\hline & $t+1$ & $0.080 * * *$ & $0.079 * *$ & 0.001 & 0.054 & -0.005 & $0.085^{* *}$ & $-0.217 * *$ & $0.288 * * *$ \\
\hline & $t+2$ & $0.077 * *$ & $0.073 *$ & 0.063 & $0.091 * *$ & -0.011 & $0.118^{* *}$ & $-0.151^{*}$ & $0.286^{* *}$ \\
\hline \multirow{3}{*}{$\begin{array}{l}\text { Capital per } \\
\text { Worker }\end{array}$} & $\mathrm{T}$ & 0.047 & 0.075 & -0.004 & $0.146 * *$ & $0.215^{* * *}$ & 0.104 & 0.016 & -0.221 \\
\hline & $t+1$ & 0.064 & 0.095 & 0.006 & 0.115 & $0.240 * *$ & $0.159 *$ & 0.033 & -0.116 \\
\hline & $t+2$ & $0.110 *$ & $0.136^{*}$ & 0.000 & $0.171^{*}$ & $0.211 *$ & $0.213 * *$ & 0.096 & -0.162 \\
\hline $\begin{array}{l}\text { Number of } \\
\text { treated }\end{array}$ & & 930 & 855 & 141 & 458 & 516 & 541 & 86 & 56 \\
\hline $\begin{array}{l}\text { Number of } \\
\text { control }\end{array}$ & & 1647 & 1529 & 255 & 820 & 900 & 960 & 143 & 105 \\
\hline
\end{tabular}

\section{B. Estonia}

\begin{tabular}{|c|c|c|c|c|c|c|c|c|c|}
\hline & & \multirow[b]{2}{*}{$\begin{array}{c}\text { All } \\
\text { exports }\end{array}$} & \multicolumn{2}{|c|}{ Type } & \multicolumn{5}{|c|}{ Participation in GVCs } \\
\hline & & & $\begin{array}{c}\text { Exports } \\
\text { of } \\
\text { goods }\end{array}$ & $\begin{array}{c}\text { Exports } \\
\text { of } \\
\text { services }\end{array}$ & $\begin{array}{l}\text { Exports of } \\
\text { intermediat } \\
\text { e products }\end{array}$ & $\begin{array}{c}\text { Exports } \\
\text { of final } \\
\text { use } \\
\text { nrodects }\end{array}$ & $\begin{array}{c}\text { Re- } \\
\text { exports }\end{array}$ & $\begin{array}{c}\text { Exports of } \\
\text { transport } \\
\text { services }\end{array}$ & $\begin{array}{c}\text { Exports of } \\
\text { other services }\end{array}$ \\
\hline Labour & $\mathrm{T}$ & $.141 * * *$ & $.105 * * *$ & $.228 * * *$ & $.122 * * *$ & $.124 * * *$ & $.161 * * *$ & $.136 * *$ & $.278 * * *$ \\
\hline \multirow[t]{2}{*}{ Productivity } & $t+1$ & $.135 * * *$ & $.119 * * *$ & $.183 * * *$ & $.125 * * *$ & $.133 * * *$ & $.207 * * *$ & $.163 * * *$ & $.238 * * *$ \\
\hline & $t+2$ & $.135 * * *$ & $.103 * * *$ & $.216 * * *$ & $.112 * * *$ & $.108 * * *$ & $.186 * * *$ & $.212 * * *$ & $.215 * * *$ \\
\hline \multirow{3}{*}{$\begin{array}{l}\text { Total Factor } \\
\text { Productivity( }\end{array}$} & $\mathrm{T}$ & -.027 & -.016 & .01 & -.013 & -.013 & .005 & .071 & -.05 \\
\hline & $t+1$ & $.12 * * *$ & $.125 * * *$ & $.239 * * *$ & $.137 * * *$ & $.116 * * *$ & $.157 * * *$ & $.234 * *$ & $.289 * * *$ \\
\hline & $t+2$ & $.123 * * *$ & $146 * * *$ & $.203 * * *$ & $.138 * * *$ & $.15^{* * *}$ & $.214 * * *$ & $.234 *$ & $.276 * * *$ \\
\hline \multirow{3}{*}{$\begin{array}{l}\text { Turnover per } \\
\text { Worker }\end{array}$} & $\mathrm{T}$ & $.174 * * *$ & $.156 * * *$ & $.217 * * *$ & $197 * * *$ & .071 & $.225 * * *$ & $.336 * * *$ & $.238 * * *$ \\
\hline & $t+1$ & $.163 * * *$ & $.161 * * *$ & $.177 * * *$ & $.192 * * *$ & .048 & $.249 * * *$ & $.308 * * *$ & $.202 * * *$ \\
\hline & $t+2$ & $.161^{* * *}$ & $.151 * * *$ & $.181 * * *$ & $.184 * * *$ & .045 & $.231 * * *$ & $.345 * * *$ & $.172 * * *$ \\
\hline \multirow{3}{*}{$\begin{array}{l}\text { Number of } \\
\text { Employees }\end{array}$} & $\mathrm{T}$ & $.058 * * *$ & $.047 *$ & $.111 * *$ & $.09 * *$ & .025 & .053 & .081 & .095 \\
\hline & $t+1$ & $.089 * * *$ & $.075 * * *$ & $.169 * * *$ & $.128 * * *$ & .064 & $.082 *$ & .095 & $.173 * * *$ \\
\hline & $t+2$ & $.096 * * *$ & $.087 * * *$ & $.168 * * *$ & $.136 * * *$ & $.097^{* *}$ & $.12 * * *$ & .118 & $.179 * * *$ \\
\hline \multirow[t]{3}{*}{ Average } & $\mathrm{T}$ & $.045^{* * *} *$ & .006 & $.12 * * *$ & .017 & .001 & $.061 * *$ & .027 & $.146^{* * *}$ \\
\hline & $t+1$ & $.063 * * *$ & $.035 * *$ & $.139 * * *$ & $.047 * *$ & .027 & $.101 * * *$ & .017 & $.184 * * *$ \\
\hline & $t+2$ & $.071 * * *$ & $.038 * *$ & $.192 * * *$ & $.062 * * *$ & .028 & $.105 * * *$ & .021 & $.225 * * *$ \\
\hline
\end{tabular}

continues on next page 


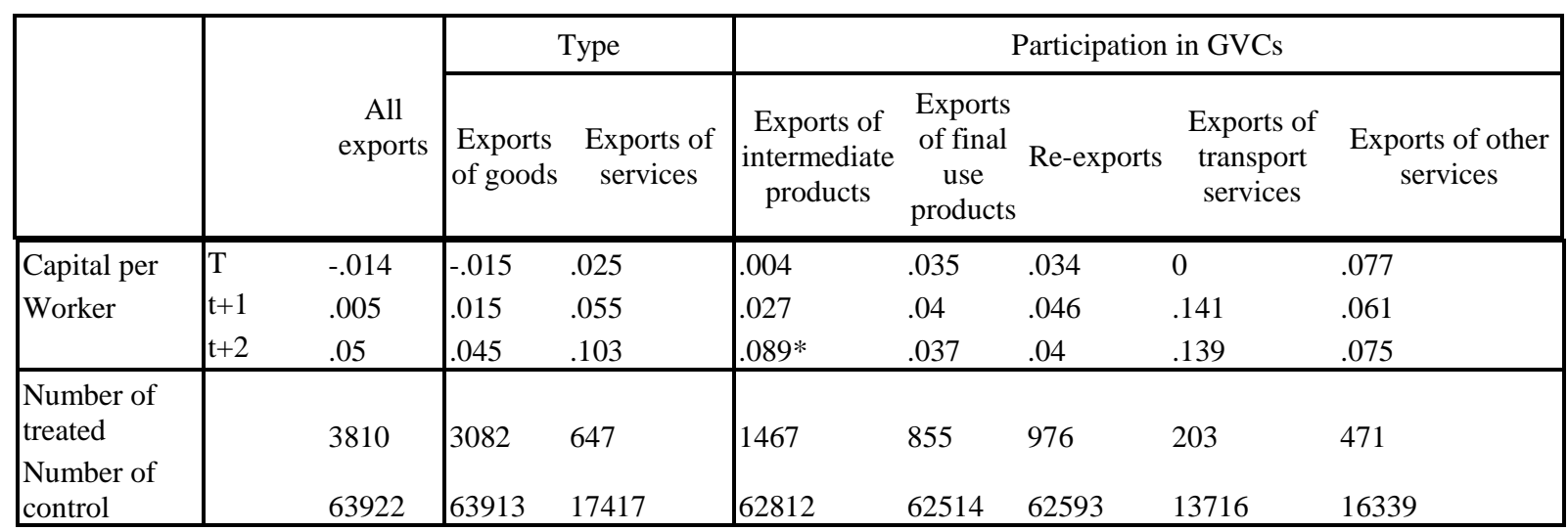

Notes: ${ }^{*}$ significant at $10 \%$; ${ }^{* *}$ significant at $5 \%$; ${ }^{* *}$ significant at $1 \%$. Dependent variables are all in logarithm. Period $t+1$ denotes 1 year after the year of export entry. The analysis includes only the sample of export entrants and matched non-exporters. Incumbent exporters that export for the full sample period are excluded from the observation.

(1) Estimated using the method of Galuscak and Lizal (2011).

(2) Estimated using the method of Levingsohn and Petrin (2003).

Source: Authors calculations.

The estimation of ATTs for some types of export entry (in particular, service exports) is constrained by the small number of treated firms. However, the ATTs for different types of export entry are fairly stable across different specifications with alternative numbers of nearest neighbours matched to each treated units or matching using caliper. Furthermore, similar results are obtained even when the definition of export entrants is altered to include intermittent exporters. The finding that export entry boosts productivity of Latvian and Estonian firms especially for the type of exports related to participation at the upstream of GVC is thus robust.

\section{Conclusions}

This study explores the causal relationship between export entry and productivity in Latvia and Estonia. It distinguishes the productivity effect for different modes of participation in global value chains. It exploits recent datasets of Latvian and Estonian firms and uses the propensity score matching (PSM) approach. Analyses were conducted in a comparative style between Latvia and Estonia. In both countries, exporters have significantly higher productivity level compared to non-exporters, even after accounting for several firm characteristics that affect productivity. Also, the productivity distribution of exporters stochastically dominates that of non-exporters. The flip side of this observation is the existence of many non-exporting firms with too low productivity level to participate in GVC through export. Indeed, about one third of non-exporters have a productivity level that is lower than the $10^{\text {th }}$ percentile of exporters' productivity distribution. At the same time, there are also many non-exporting firms with a productivity level that is higher than the median productivity of exporters.

Corroborating results of the previous literature, this study finds that larger firms and firms with higher productivity are more likely to start exporting. It also shows that export entry boosts productivity significantly, therefore supporting the learning-by-exporting hypothesis. However, export entry results in significant productivity gains only when it is related to participation in the high-value added activities found in the upstream of GVC. This is the case of entry into exports of intermediate goods, non-transport services and re-exports. For export entry that is related to participation in the downstream of GVCs such as exports of final goods or transport services, productivity gains are smaller or statistically insignificant. These empirical finding supports the paper's conjecture that empirical evidence on learning-by-exporting are scarce because they are conditional on export entrants participating in high-value added activities 
within GVC. They also underscore the importance of emerging economies to "move up the value chain" or "upgrade" their GVC activities in order to keep benefiting from GVC participation (OECD, 2013; Taglioni and Winkler, 2016).

In both Latvia and Estonia, gains in labour productivity following export entry are largest in the year of entry and level off thereafter. This suggests that productivity growth is at least partly driven by an increase in capacity utilisation, as Latvian and Estonian firms gain access to the world market. However, it is less clear if export entry results in qualitative changes such as stronger innovation capabilities, which would allow sustainable productivity growth. In order to realise larger and sustainable productivity gains following their export entry, Latvian and Estonian firms need to engage more in high-value added activities in the upstream of GVC. Policies that invigorate innovation such as supports for research cooperation between firms and research institutions would contribute to competitiveness in knowledgeintensive activities (OECD, 2017). They also improve firms' capacity to absorb knowledge transfer, thereby reinforcing learning-by-exporting.

Given that export entry increases productivity and well-paid jobs, Latvia and Estonia should aim at broadening the number of exporting firms. The large mass of firms with very low productivity that cannot cover the entry costs of export and the non-negligible mass of firms that are productive enough to enter export but are somehow not exporting are of concern. The share of exporters in Latvia is markedly lower than in Estonia, in particular in non-transport services which exports are likely to be high-value added GVC activities. It is important to identify the source of such lower export entry. 


\section{REFERENCES}

Antras, P., Chor, D., Fally, T., Hillberry, R. (2012) "Measuring the Upstreamness of Production and Trade Flows," American Economic Review, vol. 102(3), 412-16

Aw, B. Y., Robert, M. J., Winston, T. (2007). Export market participation, investments in R\&D and worker training, and the evolution of firm productivity. The World Economy, 30(1), pp. 83-104

Balsvik, R. (2011). Is labor mobility a channel for spillovers from multinationals? Evidence from Norwegian manufacturing, Review of Economics and Statistics, 93(1), 285-297.

Bayoumi, T., Coe, D. T., Helpman, E. (1999). "R\&D spillovers and global growth," Journal of International Economics, vol. 47(2), 399-428.

Beṇkovskis, K., Bērziña, S., Zorgenfreija, L. (2016) Evaluation of Latvia's re-exports using firm-level trade data, Baltic Journal of Economics, 16:1, 1-20, DOI: 10.1080/1406099X.2016.1163891

Bernard, A. B., Jensen, J. B. (1999). Exceptional exporter performance: Cause, effect, or both? Journal of International Economics, 47(1), 1-25.

Bernard, A. B., Jensen, J. B. (2004). Exporting and productivity in the USA. Oxford Review of Economic Policy, 20(3), 343-357.

Berthou, A. , Fontagné, L. (2013). "How do multi-product exporters react to a change in trade costs?" Scandinavian Journal of Economics 115, no. 2: 326-353.

Blalock, G., Gertler, P. J. (2004). Learning from exporting revisited in a less developed setting. Journal of Development Economics, 75, pp. 397-416.

Bustos, P. (2011) "Trade Liberalization, Exports, and Technology Upgrading: Evidence on the Impact of MERCOSUR on Argentinian Firms," American Economic Review, American Economic Association, vol. 101(1), pages 304-340, February.

Chaney, T. (2016) "Liquidity constrained exporters" Journal of Economic Dynamics \& Control Vol 72, $141-154$

Cohen, W.M., Levinthal, D.A. (1989) “Innovation and Learning: The Two Faces of R\&D” Economic Journal, vol. 99, (397), 569-96

Costinot, A., Vogel, J., Wang, S. (2013) "An Elementary Theory of Global Supply Chains," Review of Economic Studies, vol. 80(1), 109-144.

Crépon, B., Duguet, E., and Mairesse, J. (1998), "Research, Innovation, and Productivity: an Econometric Analysis at the Firm Level ", NBER Working Paper No. 6696.

Criscuolo,C., Haskel, J.E., Slaughter, M.J. (2009) "Global engagement and the innovation activities of firms" International Journal of Industrial Organization Vol (28), 191-202

Dasgupta, K. (2012). Learning and knowledge diffusion in a global economy. Journal of International Economics, 87, 323-336. 
Davidson, C., Heyman, F., Matusz, S., Sjöholm, F., Chun Zu, S. (2014), “Global Engagement and Occupational Structure of Firms", IFN Working Paper No. 1026.

Dedrick, J., Kraemer, K.L., Linden, G. (2010) "Who Profits from Innovation in Global Value Chains?: A Study of the iPod and Notebook PCs" Industrial and Corporate Change, Vol. 19 (1), 81-116.

De Loecker, J. (2007). Do exports generate higher productivity? Evidence from Slovenia. Journal of International Economics, 73, pp. 69-98.

De Loecker, J. (2013). Detecting learning-by-exporting. American Economic Journal: Microeconomics, 5, pp. 1-21

Dedrick, L., Kraemer, K.L., Linden, G., (2010) "Who profits from innovation in global value chains?: a study of the iPod and notebook PCs" Industrial and Corporate Change, Vol 19 (1),81-116

ECB CompNet (2014). "Micro-based evidence of EU competitiveness: the CompNet database", ECB Working Paper 1634.

Feenstra, R.C., Hanson, G.H. (2004) "Intermediaries in Entrepôt Trade: Hong Kong Re-Exports of Chinese Goods". Journal of Economics and Management Strategy, vol. 13, No. 1, March, pp. 3-35.

Fernandes, A.M., Freund, C., Pierola, M.D., (2016) "Exporter behavior, country size and stage of development: Evidence from the exporter dynamics database" Journal of Development Economics Vol 119, 121-137

Galuscak, K., Lizal, L. (2011) "The Impact of Capital Measurement Error Correction on Firm-Level Production Function Estimation," Working Papers 2011/09, Czech National Bank, Research Department.

Gereffi, G. (1999), "International Trade and Industrial Upgrading in the Apparel Commodity Chain", Journal of International Economics, 48: 37 - 70

Greenaway, D., Kneller, R. (2007). Firm heterogeneity, exporting and foreign direct investment. The Economic Journal, 117, pp. 134-61.

Griffith, R., E. Huergo, J. Mairesse, Peters, B. (2006). Innovation and Productivity Across Four European countries. Oxford Review of Economic Policy, 22(4), 483-498.

ISGEP (International Study Group on Exports and Productivity) (2008), "Understanding Cross-Country Differences in Exporter Premia: Comparable Evidence for 14 Countries" Review of World Economics Vol(1) 144- 596.

Jacobides, M.G., Knudsen, T., Augier, M. (2006) "Benefiting from innovation: Value creation, value appropriation and the role of industry architectures" Research Policy, vol. 35 (8), 1200-1221

Laursen K., Salter A. (2006). Open for innovation: The role of openness in explaining innovation performance among UK manufacturing firms. Strategic Management Journal 27: 131-150.

Levinsohn, J., Petrin, A. (2003) "Estimating Production Functions Using Inputs to Control for Unobservables" The Review of Economic Studies, 70 (2), 317-341 
Lopez-Garcia Paloma, di Mauro Filippo, the CompNet Task Force (2015) "Assessing European Competitiveness: The New CompNet Microbased Database” ECB Working Paper No. 1764.

Love, J. H., Roper, S., Zhou, Y. (2015). Experience, age and exporting performance in UK SMEs. International Business Review, 25(4), 806-819.

Masso, J., Vahter, P. (2014), “The Role of Product Level Dynamics in Export Growth and Productivity: Evidence from Estonia”, Emerging Markets Finance and Trade, Vol. 50, Number 4, pp. 42-60.

Masso, J., Meriküll, J., Vahter, P. (2013), "Benefits of distributed profit taxation versus gross profit taxation: are there effects on firms?", Journal of Comparative Economics, Vol. 41, pp. 1092-1105.

Masso, J., Rõigas, K., Vahter, P. (2015). Foreign market experience, learning by hiring and firm export performance. Review of World Economics/Weltwirtschaftsarchiv, 151(4), 659-686.

Masso, J., Vahter, P. (2015). Exporting and productivity: The effects of multi-market and multi-product export entry. Scottish Journal of Political Economy. doi:10.1111/sjpe.12077.

Masso, J., Vahter, P. (2016), "Knowledge Transfer from Multinationals through Labour Mobility: Learning from Export Experience", University of Tartu, Faculty of Economics and Business Administration Working Paper No. 99.

Mayer, T., Ottaviano, G. I. P. (2008), "The happy few: The internationalisation of European firms. New facts based on firm-level evidence", Intereconomics, Vol. 43, Issue 3, pp. 135-148.

Melitz, M. J. (2003). The Impact of Trade on Intra-Industry Reallocations and Aggregate Industry Productivity. Econometrica 71(6), 1695-1725.

Miroudot, S. , Cadestin, C. (2017), "Services In Global Value Chains: From Inputs to Value-Creating Activities", OECD Trade Policy Papers, No. 197, OECD Publishing, Paris. http://dx.doi.org/10.1787/465f0d8b-en

Muûls, M. (2015) “Exporters, importers and credit constraints" Journal of International Economics Vol (95), 333-343

OECD (2013), Interconnected Economies: Benefiting from Global Value Chains, OECD Publishing, Paris.

OECD (2017), OECD Economic Survey: Latvia, OECD Publishing, Paris.

Roper, S., Du, J., Love, J. H. (2008). Modelling the Innovation Value Chain. Research Policy, 37, 961-977.

Shaver, M.J. (2011). The benefits of geographic sales diversification: How exporting facilitates capital investment. Strategic Management Journal

Taglioni, D., Winkler, D. (2016). Making Global Value Chains Work for Development. Trade and Development series. Washington, DC: World Bank.

van Biesebroeck, J. (2005). Exporting raises productivity in sub-Saharan African manufacturing firms. Journal of International Economics, 67, pp. 373-91.

Wagner, J. (2012). International trade and firm performance: A survey of empirical studies since 2006. Review of World Economics/Weltwirtschaftliches Archiv, 148(2), 235-267. 


\section{APPENDIX 1. THE ROLE OF SKILLS IN EXPORT ENTRY OF ESTONIAN FIRMS}

\section{The role of experienced workers and skilled workers}

An earlier study (Masso et al., 2015) investigated the effect of labour mobility and spillovers on exporting by matching Estonian exports data with the data on payroll tax payments. The study focused on whether hiring managers and top specialists previously working in an exporting company helps the new employer enter new export markets. This is sometime referred to as "learning by hiring." The study found a strong geographic element notably that hiring managers and top specialists with prior experience of exporting to a specific region is associated with higher probability of the firm starting to export to that region.

This exercise replicates and extends Masso et al. (2015) by exploiting longer time period and more recent data. The dataset used in the baseline analysis is matched with the employee-employer data on payroll tax by Statistics Estonia. The matched data tracks employees' job-to-job mobility and thus can identify workers that moved from exporting firms to non-exporting firms. Because payroll tax is applied to all employees at the rate of $33 \%$ of the gross wage, its payment record allows researchers to identify an individual's gross wage and employment status at a particular firm at particular time. The data include social tax payments for all employees (the total number varies annually around 600 thousand) by all employers. In addition, the data also include information on an individual's gender and age.

The baseline probit model described in equation 2 in the main text is augmented by the employment share of managers with experience in working in exporting firm(s). As the occupational data is not available in the longitudinal data, managers and top specialists have been proxied as employees with wages belonging to the upper $20 \%$ of the wage distribution in the respective 2-digit NACE industry.

To complement this exercise, the role of skills composition in exporting is explored. The analysis further matches the employer-employee data with the microdata of Estonian Population and Housing Census, which contains social-demographic information such as age, gender, educational attainments and occupation by 4-digit ISCO codes of all Estonian individuals. The data is however only avilable for 2011. A firm's skill composition is then proxied by an index summarising the skill level of the occupational structure of its employees (Davidson et al., 2013). The index is constructed by first ranking all occupations (either at the 1-digit or at 2-digit ISCO occupations classification) by (1) their average wages or (2) the size of coefficient on the occupational variable in the Mincerian wage regressions. The estimated regression equation is such that $\ln (\text { Wage })_{j}=\alpha+\beta \times O C C_{j}+\varepsilon_{i}$, where the dependent variable is the log of the real monthly wage for individual $j$, and $O C C_{j}$ is the vector of the 1-digit or 2-digit ISCO occupational codes. The coefficient $\beta$ is the returns to respective occupation used for ranking the occupations. $\varepsilon_{i}$ is the error term.

The skills index is then calculated for each firm as the weighted average according to its occupational mix. Following Davidson et al. (2013), the skill index for form $f$ in year $t$ which is denoted as $S_{f t}$, is calculated as $S_{f t}=\sum_{k} \frac{\lambda_{f t}^{k} R^{k}}{K}$, where the term $R^{k}$ denotes the skill ranking of occupation $k$, where a higher $k$ means a more skilled occupation. The index is bounded between 0 and 1 , and a value of 0.5 of the index would indicate that the employment is evenly distributed across the occupations. The index takes higher values if the employment is allocated towards higher skilled occupations.

Because the occupational data is available at only one point of time, this exercise runs a crosssectional OLS regression where a dummy variable indicating that a firm is an exporter is regressed against 
the skill composition. The coefficient in this regression indicates correlation between skill intensity and export status and not necessarily causality.

Exporters tend to hire a higher share of experienced workers and managers as compared to nonexporters (Table 11). For instance, on average 25\% (10\%) of employees (managers) in exporting firms have an experience working for other exporting firms while merely $17 \%$ (7\%) of employees (managers) with a similar work experience are employed by non-exporting firms (column 1 and 2). This difference is more pronounced when focusing on employees or managers who previously worked for exporting firms in the same 2-digit NACE industry (column 3 and 4). Among different types of exporters, firms engaging in re-exporting and exports of non-transport services have a relatively lower share of experienced employees or managers from the same industry compared to exporters in general. Those exporters may be facing shortages of experienced workers that are constraining their exports and participation to GVC. Exporters are also more skill intensive in terms of occupational structure than non-exporters, although the difference is not so large in general and for goods exporters this observation depends on the approach to rank occupations (column 5 and 6). It is however apparent that exporters of non-transport services are more skill intensive than non-exporters, indicating that shortages of skilled workers can constrain their participation to GVC the most.

Table 11. The employment share of workers with export experience and skill composition

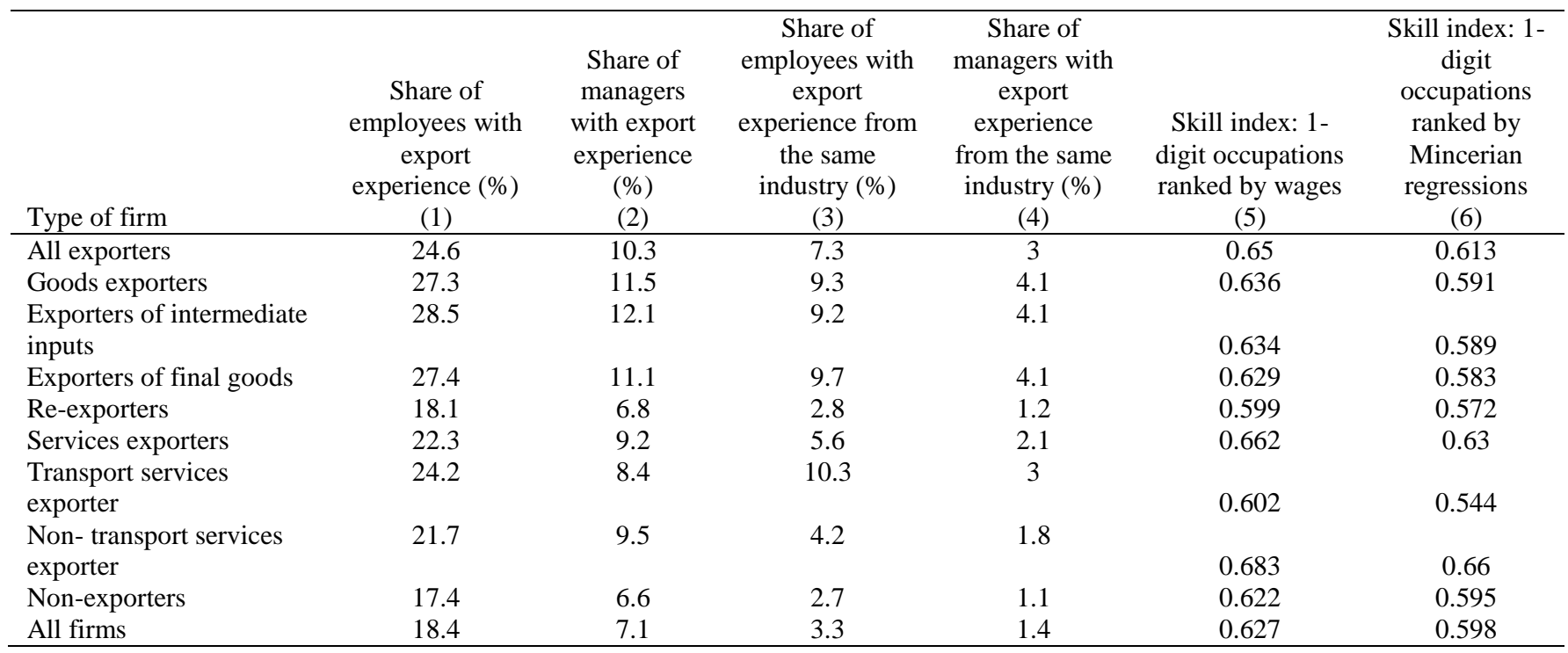

Note: The export experience data is for 2007-2014, the skill composition data for 2011.

Source: Authors calculations.

A higher share of managers with exporting experience is positively associated with the probability of export entry, except for exports of transport services. A significant conclusion is also that the export experience has stronger benefit if it has a strong industry-specific focus. Furthermore, export experience has strong positive correlation with exporting in the case of almost all different export dummies (Table 12).

However, the regression analysis shows that the skills index is almost always positively correlated with exporting at least at the 5\% level of significance. The correlation is stronger in the case of goods exporting as compared to services exporters. Export entry in final goods shows somewhat stronger correlation with skills as compared to other entry modes, but the same does not apply for exporting. Concerning different kinds of services, exporting of knowledge-intensive services have a strong correlation with skills index, as the production of these services probably requires high skills in the first place. 
Table 12. Regression coefficients of export experience and skills intensity

\begin{tabular}{|c|c|c|c|c|c|c|}
\hline \multirow[b]{2}{*}{ Type of exporter } & \multicolumn{4}{|c|}{ Probability of export entry } & \multicolumn{2}{|c|}{ Export dummy } \\
\hline & $\begin{array}{c}\text { Share of } \\
\text { employees } \\
\text { with } \\
\text { export } \\
\text { experience } \\
\text { (1) }\end{array}$ & $\begin{array}{c}\text { Share of } \\
\text { managers } \\
\text { with } \\
\text { export } \\
\text { experience } \\
\text { (2) }\end{array}$ & $\begin{array}{c}\text { Share of } \\
\text { employees } \\
\text { with } \\
\text { export } \\
\text { experience } \\
\text { from the } \\
\text { same } \\
\text { industry } \\
\text { (3) }\end{array}$ & $\begin{array}{l}\text { Share of } \\
\text { managers } \\
\text { with } \\
\text { export } \\
\text { experience } \\
\text { from the } \\
\text { same } \\
\text { industry } \\
(4)\end{array}$ & $\begin{array}{l}\text { Skill index: } \\
\text { 1-digit } \\
\text { occupations } \\
\text { ranked by } \\
\text { wages } \\
\text { (5) }\end{array}$ & $\begin{array}{l}\text { Skill index: } \\
\text { 1-digit } \\
\text { occupations } \\
\text { ranked by } \\
\text { Mincerian } \\
\text { regressions } \\
\text { (6) }\end{array}$ \\
\hline All exporters & $0.429 * * *$ & $0.502 * * *$ & $0.426 * * *$ & $0.614 * * *$ & $0.322 * * *$ & $0.356 * * *$ \\
\hline Good exporters & $0.301 * * *$ & $0.450 * * *$ & $0.319 * * *$ & $0.596 * * *$ & $0.312 *$ & $0.510 * * *$ \\
\hline Exporters of final goods & $0.498 * * *$ & $0.502 * * *$ & $0.454 * * *$ & $0.557 * * *$ & $0.503 * * *$ & $0.510 * * *$ \\
\hline Exporters of intermediate goods & $0.405^{* * *}$ & $0.511 * * *$ & $0.451 * * *$ & $0.460 * *$ & $0.489 * * *$ & $0.458 * * *$ \\
\hline Re-exporters & $0.464 * * *$ & $0.330 * * *$ & $0.412 * * *$ & $0.563 * * *$ & $1.100 * * *$ & $0.630 * *$ \\
\hline Services exporters & $0.544 * * *$ & $0.431 * * *$ & $0.501 * * *$ & $0.474 * * *$ & 0.253 & $0.324 *$ \\
\hline Transport services exporters & $0.222 * *$ & $0.411 * * *$ & $0.439 * * *$ & $0.592 * * *$ & $0.486 * *$ & -0.203 \\
\hline Non-transport services exporters & $0.600 * * *$ & $0.280 * *$ & $0.647 * * *$ & $0.741 * * *$ & $0.358 *$ & $0.467 * *$ \\
\hline
\end{tabular}

Note: The table reports the coefficients on the export experience and the skills intensity in the augumented probit model and crosssectional OLS model. * significant at 10\%; ${ }^{* *}$ significant at $5 \%$; ${ }^{* * *}$ significant at $1 \%$. The dependent variables are dummy variables corresponding to different types of exporters and export entry. The estimation includes the same explanatory variables are same as the baseline probit model described in equation 2 in the main text.

\section{Knowledge spillovers from multinational enterprises through workers' mobility}

Labour mobility has been considered as one of the key channels of knowledge transfer from multinational enterprises (MNEs) to local firms (Dasgupta 2012, Balsvik 2011). Whereas most literature on knowledge spillovers from MNEs focused on the impact on productivity of local firms, benefits of MNEs presence may reveal themselves via the transfer of export-related knowledge which helps local firms to start exporting or expand their scope of exports to new products or markets. This subsection examines the role of employees or managers with experience in MNEs in facilitating the export entry (more comprehensive analysis can be found in Masso and Vahter, 2016). The analysis exploits the same matched employer-empoyee data used above.

The Probit model described in equation 2 in the main text is augmented with the share of employees and managers that previously worked in MNEs. Furthermore, in order to address the possible endogeneity between export decision and decisions about hiring people with export experience (Masso et al., 2015), the analysis use instrumental variable (IV) approach. The shares of ex-MNEs employees and managers in all employees are instrumented by the share of current employees whose reason for moving to the particular enterprise was the closure of their previous employer. While such share is correlated with availability of exMNE employees it should be exogenous to the firms considering export entry.

The estimation results in Table 14 show that a higher employment share of ex-MNEs employees and managers increases significantly the probability of export entry by Estonian firms, even after controlling for firm size, age, share of managers and labour productivity level. The marginal effects at sample means are also positive and significant: a 10 percentage points increase in the share of MNE-experienced employees (managers) is associated with about a 5\% (10\%) higher probability that the firm exports. To give further indication of the magnitude of these correlations, a one standard deviation increase in the share of MNE-experienced managers in the workforce of a firm is associated with about $35 \%$ higher propensity of the firm to export. 
Table 13. MNE experience of employees: estimated relationship with exporting

\begin{tabular}{|c|c|c|}
\hline & (1) & (2) \\
\hline Share of employees with experience from MNEs & $\begin{array}{l}0.205 \\
(0.110)^{*}\end{array}$ & \\
\hline $\begin{array}{l}\text { Share of managers and high-wage employees } \\
\text { with experience from MNEs }\end{array}$ & & $\begin{array}{l}0.308 \\
(0.134)^{* *}\end{array}$ \\
\hline Share of managers at firm & $\begin{array}{l}0.103 \\
(0.052)^{* *}\end{array}$ & $\begin{array}{l}0.099 \\
(0.052)^{*}\end{array}$ \\
\hline Log labour productivity (t-1) & $\begin{array}{l}0.401 \\
(0.019)^{* * *}\end{array}$ & $\begin{array}{l}0.401 \\
(0.019)^{* * * *}\end{array}$ \\
\hline Number of observations & 15760 & 15760 \\
\hline \multicolumn{3}{|l|}{ Marginal effects } \\
\hline Share of employees with experience from MNEs & $\begin{array}{l}0.553 \\
(0.105)^{* * *}\end{array}$ & \\
\hline $\begin{array}{l}\text { Share of managers and high-wage employees } \\
\text { with experience from MNEs }\end{array}$ & & $\begin{array}{l}0.965 \\
(0.178)^{* * *}\end{array}$ \\
\hline
\end{tabular}

Notes: ${ }^{* * *}{ }^{* * *}$ each corresponds to significance at $10 \%, 5 \%$ and $1 \%$ level respectively. Robust standard errors are in parentheses. The explanatory variables included in the estimation but not reported in the table are firm size, firm age, cash to total assets, and NACE 2-digit level sector dummies.

Source: Authors calculations 


\section{APPENDIX 2. EXPORTS AND INNOVATION OF ESTONIAN FIRMS}

One important channel through which exports boost productivity is by stimulating innovation. There may be important learning effects from exporting that are realised in product innovation, process innovation or other types of innovation. Some type of exports, such as those to advanced economies or exports of multiple products to multiple destinations may have larger scope for absorbing advanced technologies and other useful knowledge for innovation. Innovation in turn increases the likelihood that a firm starts exporting. Developing new products or improving product quality raises firms' competitiveness in the foreign markets. Higher productivity realised by process innovation makes it easier for firms to cover the entry cost of exports.

This section investigates the relationship between exporting and innovation by exploiting the microdata of the Community Innovation Survey (CIS) of period 2010-2012 by the European Commission. It observes key types of innovation realised by Estonian firms during this period, such as product innovation, process innovation, organisational innovation, and marketing innovation, which are defined by the Oslo Manual of innovation studies. Radical product innovations which are new-to-market product innovations and radical process innovation which are new-to-Estonia process innovations are also observed. The CIS survey also includes information on export status during the same period which is used here. Unfortunately, the sample size of CIS Survey is very much smaller than the baseline dataset.

In the spirit of the "innovation (or knowledge) production function," (Crépon et al. 1998; Laursen and Salter 2006; Roper et al. 2008) this section estimates a Probit model where innovation output is assumed to be a function of various innovation inputs and exports. Innovation output is proxied by various technological and non-technological innovation indicators from the CIS survey. The dependent variable is a dummy variable taking a value 1 if the firm reports a specific type of innovation indicator and zero otherwise. Export status is captured by the export dummy, as in equation 1 in the main text. The Probit model also includes 2-digit NACE sector dummies and firm size (log of employment) as explanatory variables. The positive and significant coefficients on export dummy summarised in Table 14 indicate that exporters are significantly more likely to be engaging in innovation ranging from new product development to organisational changes and new marketing, compared to non-exporters of the same size and in the same industry.

Table 14. Exporter's premium in innovation

\begin{tabular}{|c|c|c|c|c|c|c|}
\hline & 1 & 2 & 3 & 4 & 5 & 6 \\
\hline $\begin{array}{l}\text { Dependent } \\
\text { variable: }\end{array}$ & $\begin{array}{l}\text { Product } \\
\text { innovation }\end{array}$ & $\begin{array}{l}\text { Process } \\
\text { innovation }\end{array}$ & $\begin{array}{l}\text { Radical product } \\
\text { innovation }\end{array}$ & $\begin{array}{l}\text { Radical } \\
\text { process } \\
\text { innovation }\end{array}$ & $\begin{array}{l}\text { Organisational } \\
\text { innovation }\end{array}$ & $\begin{array}{l}\text { Marketing } \\
\text { innovation }\end{array}$ \\
\hline Export dummy & $0.112 * *$ & $0.163 * * *$ & $0.0814^{* * *}$ & 0.0247 & $0.117 * * *$ & $0.125 * * *$ \\
\hline & $(3.25)$ & $(4.50)$ & $(2.75)$ & $(1.11)$ & $(3.55)$ & $(3.76)$ \\
\hline Firm size & $\begin{array}{l}0.0344 * * \\
(3.27)\end{array}$ & $\begin{array}{l}0.0760 * * * \\
(7.44)\end{array}$ & $\begin{array}{l}0.0419 * * * \\
(5.17)\end{array}$ & $\begin{array}{l}0.0239 * * * \\
(3.90)\end{array}$ & $\begin{array}{l}0.0479 * * * \\
(5.03)\end{array}$ & $\begin{array}{l}0.0380 * * * \\
(3.95)\end{array}$ \\
\hline Sector dummies & Yes & Yes & Yes & Yes & Yes & Yes \\
\hline $\mathrm{N}$ & 1681 & 1683 & 1552 & 1472 & 1675 & 1688 \\
\hline
\end{tabular}

Note: own calculations based on Estonian firm-level datasets. Marginal effects. Robust z-statistics in parentheses. *significant at $5 \%$; ** significant at 1\%; ${ }^{* * *}$ significant at 0.1\%. CIS2012 dataset, period 2010-2012.

Source: Authors calculations.

Next, it is examined if the exporter's premium in innovation is driven by exports or innovation efforts such as R\&D, research collaboration and external knowledge sourcing activities. The Probit model is augmented to include innovation input variables often employed in studies of the innovation value chain (e.g. Roper et al. 2008; Laursen and Salter 2006) or structural models of R\&D, innovation and productivity (e.g. Griffith et al. 2006). The results summarised in Table 15 show that the coefficient on export dummy 
is no longer significant once various inputs to innovation are taken into account, except for marketing innovation. Thus exporter's premium in innovation is mostly accounted for by exporters having higher level of innovation inputs. This however, does not mean that exports are not stimulating innovation, since higher innovation inputs can be induced by exports. For instance, numerous literature report that export entry increase innovation inputs such as R\&D, purchase of new technology and other external knowledge sourcing (Aw et al., 2009; Bustos, 2011; Criscuolo et al., 2010).

Table 15. The determinants of innovation

\begin{tabular}{|c|c|c|c|c|c|c|}
\hline Dependent variable: & $\begin{array}{c}1 \\
\text { Product } \\
\text { innovation }\end{array}$ & $\begin{array}{l}2 \\
\text { Process } \\
\text { innovation }\end{array}$ & $\begin{array}{c}3 \\
\text { Radical } \\
\text { product } \\
\text { innovation }\end{array}$ & $\begin{array}{c}4 \\
\text { Radical } \\
\text { process } \\
\text { innovation }\end{array}$ & $\begin{array}{l}5 \\
\text { Organisational } \\
\text { innovation }\end{array}$ & $\begin{array}{c}6 \\
\text { Marketing } \\
\text { innovation }\end{array}$ \\
\hline Internal R\&D & $\begin{array}{c}0.0656 * * \\
(3.23)\end{array}$ & $\begin{array}{c}0.107 * * * \\
(4.34)\end{array}$ & $\begin{array}{c}0.0559 * * * \\
(3.41)\end{array}$ & $\begin{array}{c}0.0405 * * \\
(2.65)\end{array}$ & $\begin{array}{l}0.0252 \\
(0.85)\end{array}$ & $\begin{array}{l}0.0205 \\
(0.70)\end{array}$ \\
\hline Continuous R\&D & $\begin{array}{c}0.0642 * * \\
(2.60)\end{array}$ & $\begin{array}{l}-0.0406 \\
(-1.31)\end{array}$ & $\begin{array}{l}0.0237 \\
(1.36)\end{array}$ & $\begin{array}{c}0.00927 \\
(0.63)\end{array}$ & $\begin{array}{l}0.0488 \\
(1.46)\end{array}$ & $\begin{array}{c}0.00867 \\
(0.27)\end{array}$ \\
\hline $\begin{array}{l}\text { Buying in external } \\
\text { R\&D }\end{array}$ & $\begin{array}{c}0.174 * * * \\
(10.34)\end{array}$ & $\begin{array}{c}0.0228 \\
(0.93)\end{array}$ & $\begin{array}{c}0.0674 * * * \\
\quad(4.70)\end{array}$ & $\begin{array}{l}0.0214 \\
(1.57)\end{array}$ & $\begin{array}{c}0.0492 \\
(1.85)\end{array}$ & $\begin{array}{c}0.166^{* * * *} \\
(6.80)\end{array}$ \\
\hline Formal cooperation & $\begin{array}{c}0.0832 * * * \\
(4.56)\end{array}$ & $\begin{array}{c}0.0954 * * * \\
\quad(4.53)\end{array}$ & $\begin{array}{l}0.0768 * * * \\
\quad(5.23)\end{array}$ & $\begin{array}{l}0.0512 * * * \\
\quad(3.76)\end{array}$ & $\begin{array}{c}0.0917 * * * \\
(3.58)\end{array}$ & $\begin{array}{c}0.00908 \\
(0.35)\end{array}$ \\
\hline $\begin{array}{l}\text { Knowledge sourcing } \\
\text { from within firm }\end{array}$ & $\begin{array}{c}0.129 * * * \\
(7.00)\end{array}$ & $\begin{array}{c}0.0704 * * \\
(3.08)\end{array}$ & $\begin{array}{c}0.0880 * * * \\
(4.92)\end{array}$ & $\begin{array}{c}0.0440 * * \\
(3.02)\end{array}$ & $\begin{array}{c}0.0817 * * \\
(2.94)\end{array}$ & $\begin{array}{c}0.0600^{*} \\
(2.18)\end{array}$ \\
\hline $\begin{array}{l}\text { Knowledge sourcing } \\
\text { from clients }\end{array}$ & $\begin{array}{c}0.0881 * * * \\
(5.07)\end{array}$ & $\begin{array}{c}0.00803 \\
(0.34)\end{array}$ & $\begin{array}{l}0.0519 * * * \\
\quad(3.72)\end{array}$ & $\begin{array}{l}0.0101 \\
(0.79)\end{array}$ & $\begin{array}{c}0.0466 \\
(1.79)\end{array}$ & $\begin{array}{r}0.0322 \\
(1.27)\end{array}$ \\
\hline $\begin{array}{l}\text { Knowledge sourcing } \\
\text { from suppliers }\end{array}$ & $\begin{array}{c}0.0124 \\
(0.70)\end{array}$ & $\begin{array}{c}0.223 * * * \\
(13.66)\end{array}$ & $\begin{array}{l}-0.0112 \\
(-0.78)\end{array}$ & $\begin{array}{c}0.0434 * * * \\
\quad(3.38)\end{array}$ & $\begin{array}{c}0.0544 * \\
(2.26)\end{array}$ & $\begin{array}{c}0.0910 * * * \\
(3.93)\end{array}$ \\
\hline $\begin{array}{l}\text { Knowledge sourcing } \\
\text { from universities and } \\
\text { research institutes }\end{array}$ & $\begin{array}{l}-0.0398 \\
(-1.50)\end{array}$ & $\begin{array}{c}-0.0910^{* *} \\
(-3.04)\end{array}$ & $\begin{array}{l}-0.0105 \\
(-0.56)\end{array}$ & $\begin{array}{c}-0.00824 \\
(-0.53)\end{array}$ & $\begin{array}{c}0.00720 \\
(0.20)\end{array}$ & $\begin{array}{l}0.0488 \\
(1.43)\end{array}$ \\
\hline Foreign ownership & $\begin{array}{c}-0.00785 \\
(-0.50)\end{array}$ & $\begin{array}{r}0.0307 \\
(1.69)\end{array}$ & $\begin{array}{c}0.0134 \\
(0.91)\end{array}$ & $\begin{array}{c}0.00259 \\
(0.19)\end{array}$ & $\begin{array}{c}0.0329 \\
(1.52)\end{array}$ & $\begin{array}{l}-0.0377 \\
(-1.71)\end{array}$ \\
\hline Export dummy & $\begin{array}{l}-0.0187 \\
(-0.92)\end{array}$ & $\begin{array}{c}0.0432 \\
(1.59)\end{array}$ & $\begin{array}{c}-0.00291 \\
(-0.13)\end{array}$ & $\begin{array}{l}-0.0102 \\
(-0.52)\end{array}$ & $\begin{array}{c}0.0410 \\
(1.37)\end{array}$ & $\begin{array}{c}0.0573 * \\
(1.99)\end{array}$ \\
\hline Innovation grants & $\begin{array}{c}0.00657 \\
(0.27)\end{array}$ & $\begin{array}{c}0.111 * * * \\
(3.86)\end{array}$ & $\begin{array}{r}0.0247 \\
(1.36)\end{array}$ & $\begin{array}{c}0.0285 \\
(1.83)\end{array}$ & $\begin{array}{c}0.000442 \\
(0.01)\end{array}$ & $\begin{array}{r}0.0417 \\
(1.33)\end{array}$ \\
\hline $\begin{array}{l}\text { Innovation grants from } \\
\text { the EU }\end{array}$ & $\begin{array}{c}0.00542 \\
(0.17)\end{array}$ & $\begin{array}{l}-0.0159 \\
(-0.41)\end{array}$ & $\begin{array}{c}0.0332 \\
(1.38)\end{array}$ & $\begin{array}{c}-0.00333 \\
(-0.17)\end{array}$ & $\begin{array}{l}0.102 * \\
(2.36)\end{array}$ & $\begin{array}{c}0.0756 \\
(1.80)\end{array}$ \\
\hline Firm size & $\begin{array}{c}-0.0156^{*} \\
(-2.23)\end{array}$ & $\begin{array}{c}0.0193 * \\
(2.38)\end{array}$ & $\begin{array}{c}0.00790 \\
(1.25)\end{array}$ & $\begin{array}{c}0.00498 \\
(0.94)\end{array}$ & $\begin{array}{c}0.0129 \\
(1.46)\end{array}$ & $\begin{array}{c}0.0108 \\
(1.21)\end{array}$ \\
\hline $\begin{array}{l}\text { Share of employees } \\
\text { with higher degree } \\
>10 \%\end{array}$ & $\begin{array}{c}-0.00127 \\
(-0.07) \\
\end{array}$ & $\begin{array}{c}-0.0373 * \\
(-1.98) \\
\end{array}$ & $\begin{array}{l}0.0171 \\
(0.97) \\
\end{array}$ & $\begin{array}{c}0.00866 \\
(0.55) \\
\end{array}$ & $\begin{array}{l}0.0368 \\
(1.59) \\
\end{array}$ & $\begin{array}{r}0.0347 \\
(1.52)\end{array}$ \\
\hline Sector dummies & Yes & Yes & Yes & Yes & Yes & Yes \\
\hline $\mathrm{N}$ & 1681 & 1683 & 1552 & 1472 & 1675 & 1688 \\
\hline
\end{tabular}

Note: Marginal effects. Robust z-statistics in parentheses. *significant at $5 \%$; ${ }^{* *}$ significant at $1 \%$; ${ }^{* *}$ significant at $0.1 \%$. CIS2012 dataset, period 2010 2012.

Source: Authors calculations. 
It is worth noting that innovation inputs have the expected signs and significance in the estimated knowledge production function. Own R\&D of the firm is positively associated with product and process innovation and more radical innovation, but not organizational or marketing innovation. Knowledge sourcing and formal co-operation with external partners matters a lot for successful innovation. Knowledge sourcing from clients matters for product innovation, knowledge sourcing from suppliers is associated with higher propensity of process innovation (e.g. similarly to Griffith et al. 2006 results from Western Europe).

Finally, the CIS data is matched with the firm data used in the main analysis to uncover the type of exports that is more correlated with innovation. Table 16 reports the marginal effects form the estimation where dependent variable is a dummy variable indicating specific type of innovation (column) and the main explanatory variable is the dummy variable indicating specific type of exports (rows). Sector dummies and firm size are included in all estimation as control variables. ${ }^{21}$ Export dummy in this case indicates the export status in 2010, while the innovation is reported during 2010-2012. The direction of causality runs from exports to innovation rather than as in the above exercises where export dummies indicated contemporaneous export.

Overall, the association between exports and innovation is less clear than in Table 15, suggesting that there is sizable self-selection of innovative firms into exports. Nevertheless, a clear positive relationship is still found in the case of process innovation, to lesser extent in the case of product, organisational or marketing innovation. Most notably, the positive correlation of exporting and innovation is clear and evident in the case of services exports. Services exports is likely to entail (radical) product innovation, process innovation and to a weaker extent organisational innovation. Such finding is in line with the large productivity gains found for service exports, namely exports of non-transport services.

Table 16. Types of exporting and innovation

\begin{tabular}{|c|c|c|c|c|c|c|}
\hline Dependent variable: & $\begin{array}{l}\text { Product } \\
\text { innovation }\end{array}$ & $\begin{array}{l}\text { Process } \\
\text { innovation }\end{array}$ & $\begin{array}{l}\text { Radical } \\
\text { product } \\
\text { innovation }\end{array}$ & $\begin{array}{l}\text { Radical } \\
\text { process } \\
\text { innovation } \\
\text { (new to } \\
\text { Estonia) } \\
\end{array}$ & $\begin{array}{l}\text { Organisational } \\
\text { innovation }\end{array}$ & $\begin{array}{l}\text { Marketing } \\
\text { innovation }\end{array}$ \\
\hline \multirow[t]{2}{*}{ Goods exporter } & 0.00471 & $0.0688 *$ & 0.0375 & 0.0384 & 0.0475 & 0.0485 \\
\hline & $(0.12)$ & $(1.75)$ & $(1.16)$ & $(1.44)$ & $(1.33)$ & $(1.28)$ \\
\hline \multirow[t]{2}{*}{ Intermediate inputs exporter } & 0.00956 & $0.112 * * *$ & 0.0315 & 0.0290 & $0.0702 *$ & $0.0717 *$ \\
\hline & $(0.23)$ & $(2.61)$ & $(0.94)$ & $(1.10)$ & $(1.78)$ & $(1.75)$ \\
\hline \multirow[t]{2}{*}{ Final goods exporter } & 0.0229 & $0.121 * * *$ & 0.00894 & 0.0378 & $0.103 * *$ & 0.0470 \\
\hline & $(0.50)$ & $(2.75)$ & $(0.22)$ & $(1.38)$ & $(2.44)$ & $(1.08)$ \\
\hline \multirow[t]{2}{*}{ Services exporter } & $0.0726 * *$ & $0.0593 * *$ & $0.0635 * * *$ & 0.0280 & $0.0477 *$ & 0.0300 \\
\hline & $(2.56)$ & $(2.03)$ & $(2.67)$ & $(1.27)$ & $(1.65)$ & $(1.03)$ \\
\hline
\end{tabular}

Note: own calculations based on Estonian firm-level datasets. Marginal effects. Robust z-statistics in parentheses. *significant at $5 \%$; ${ }^{* *}$ significant at $1 \% ;{ }^{* * *}$ significant at $0.1 \%$. CIS2012 dataset merged with Estonia's firm level trade data, period 2010-2012. Each cell shows marginal effect of a particular kind of exporting on a particular type of innovation. Each regression included also size and sector controls. All regressions except the ones on services exports are based on the sample of manufacturing firms. Services exports 'effects' are estimated based on the sample of all firms.

Source: Authors calculations

\footnotetext{
${ }^{21}$ Due to the very small sample size, some types of exporters are not identified.
} 